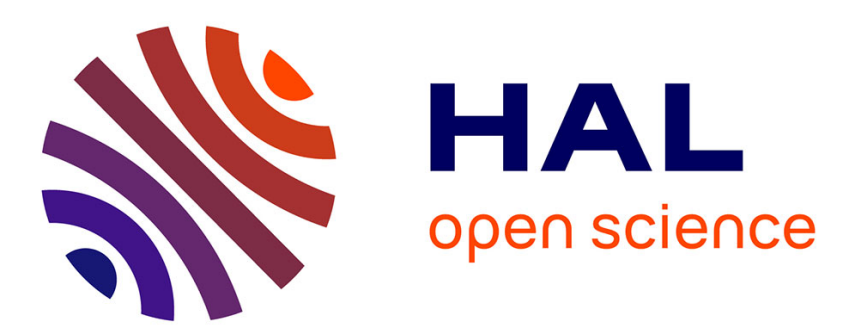

\title{
Pre-Alpine (Variscan) inheritance: a key for the location of the future Valaisan Basin (Western Alps).
}

Michel Ballevre, Paola Manzotti, Giorgio Vittorio Dal Piaz

\section{To cite this version:}

Michel Ballevre, Paola Manzotti, Giorgio Vittorio Dal Piaz. Pre-Alpine (Variscan) inheritance: a key for the location of the future Valaisan Basin (Western Alps).. Tectonics, 2018, 37 (3), pp.786-817. 10.1002/2017TC004633 . insu-01717267

\section{HAL Id: insu-01717267 https://hal-insu.archives-ouvertes.fr/insu-01717267}

Submitted on 22 May 2018

HAL is a multi-disciplinary open access archive for the deposit and dissemination of scientific research documents, whether they are published or not. The documents may come from teaching and research institutions in France or abroad, or from public or private research centers.
L'archive ouverte pluridisciplinaire HAL, est destinée au dépôt et à la diffusion de documents scientifiques de niveau recherche, publiés ou non, émanant des établissements d'enseignement et de recherche français ou étrangers, des laboratoires publics ou privés. 


\section{Tectonics}

\section{RESEARCH ARTICLE}

10.1002/2017TC004633

\section{Special Section:}

Orogenic cycles: from field

observations to global

geodynamics

\section{Key Points:}

- Granitoids are mainly Late

Carboniferous in the Helvetic

basement and Permian in the

Penninic basement

- Small, short-lived (Westphalian

D-Stephanian) basins on top of the

Helvetic basement contrast with the

earlier and long-lived basin along

the eastern border of the Penninic

domain

- The East Variscan Shear Zone allowed the formation of the Zone Houillère

basin and was reactivated during the opening of the Valaisan Basin

\section{Supporting Information:}

- Supporting Information S1

Correspondence to:

M. Ballèvre,

michel.ballevre@univ-rennes1.fr

\section{Citation}

Ballèvre, M., Manzotti, P., \& Dal Piaz, G. V. (2018). Pre-Alpine (Variscan) inheritance: A key for the location of the future Valaisan Basin (Western Alps). Tectonics, 37, 786-817. https:// doi.org/10.1002/2017TC004633

Received 19 APR 2017 Accepted 8 FEB 2018

Accepted article online 14 FEB 2018

Published online 7 MAR 2018

C2018. American Geophysical Union. All Rights Reserved.

\section{Pre-Alpine (Variscan) Inheritance: A Key for the Location of the Future Valaisan Basin (Western Alps)}

\author{
M. Ballèvre ${ }^{1}$ iD, P. Manzotti ${ }^{2}$ iD, and G. V. Dal Piaz ${ }^{3}$ iD \\ ${ }^{1}$ Géosciences Rennes, Université de Rennes 1, Rennes, France, ${ }^{2}$ Institut des Sciences de la Terre, Geopolis, Université de \\ Lausanne, Lausanne, Switzerland, ${ }^{3}$ Dipartimento di Geoscienze, Università degli Studi, Padua, Italy
}

Abstract The boundary between the Helvetic and the Penninic (=Briançonnais) Zones has long been recognized as a major fault ("Penninic Front") in the Western Alps. A narrow oceanic domain has been postulated at least along part of this boundary (the Valaisan Basin). However, the information provided by the pre-Triassic basement has not been fully exploited and will be discussed here in detail. The igneous and metamorphic history of the pre-Triassic basement shows significant differences between the External Massifs from the Helvetic Zone, with abundant Late Carboniferous granites, and the basement of the Briançonnais Zone, including the Internal Massifs (Dora-Maira, Gran Paradiso, and Monte Rosa), devoid of Carboniferous granites. A major coal-bearing basin, the "Zone Houillère," opened along this boundary. This limnic intramontane basin has never been properly investigated. The Zone Houillère is not comparable with the external, paralic, flexural, basins on both sides of the Variscan belt but shows similarities with the Saar-Saale Basin. Like the latter, we interpret the Zone Houillère as a transtensional basin opened along a major, crustal-scale, fault zone, namely, the East Variscan Shear Zone. The Permian magmatism and sedimentation displays contrasting distributions, being absent or very localized in the Helvetic Zone, and widespread in the Penninic Zone. The above data indicate that the structural inheritance from the Variscan belt plays a major role in defining the future location of the Valaisan Basin, that is, the boundary between the European paleomargin and the Briançonnais microcontinent.

\section{Introduction}

In many mountain belts, major tectonic boundaries are frequently inherited from the precollision history. In the Alpine belt, much attention has been devoted to the potential reactivation (inversion) of high-angle (listric) normal faults and low-angle detachments that developed during the rifting stage, related to the opening of the Piemonte-Liguria Ocean from mid-Jurassic times onward. They segmented the passive paleomargins into narrow, elongated domains mainly parallel to the trend of the future mountain belt (e.g., Beltrando, Rubatto, \& Manatschal, 2010; Butler et al., 2006; Epin et al., 2017; Gillcrist et al., 1987; Mohn et al., 2014). Less attention has been devoted to pre-Mesozoic faults affecting the prerift basement, which may control the location and kinematics of the Mesozoic synrift normal faults. Such control is known from present-day passive margins such as in southern Norway (Phillips et al., 2016) and in partly inverted rift basins, like the North Sea (Fazlikhani et al., 2017). Much more difficult is the recognition of such processes of repeated reactivation in a collision belt, where such preorogenic structures may be severely overprinted during the subduction/collision process. However, an example for inheritance from a previous orogeny is provided in the Western Alps through the examination of superimposed Variscan (Carboniferous) and Alpine (Late Cretaceous to Recent) orogenies.

In the Western Alps (Figure 1), the boundary between the Helvetic(-Dauphinois) units on the one hand and the Briançonnais, Piemonte-Liguria, and Sesia-Dent Blanche units (collectively termed Penninic by Argand, 1911) on the other hand has been recognized since a long time as a major tectonic boundary (Argand, 1911), often referred to the Penninic Front. The first-order differences in the stratigraphic sequences between the Helvetic domain and the Briançonnais domain (e.g., Haug, 1925) have been integrated into a model of development of a passive paleomargin during the Triassic and the Jurassic (e.g., Lemoine, 1985; Lemoine et al., 1986; Lemoine \& Trümpy, 1987). Although differences in the Paleozoic basement of these domains were noted from time to time (e.g., Boriani et al., 1974; Debelmas, 1974), the emphasis was put on the differences between the Mesozoic sequences and their interpretation for the Mesozoic rift-drift history.

However, the zone of transition from the Helvetic to the Penninic (Briançonnais) domain along the Penninic Front is not yet sufficiently well understood and/or subject of controversies. Three major questions remain. 


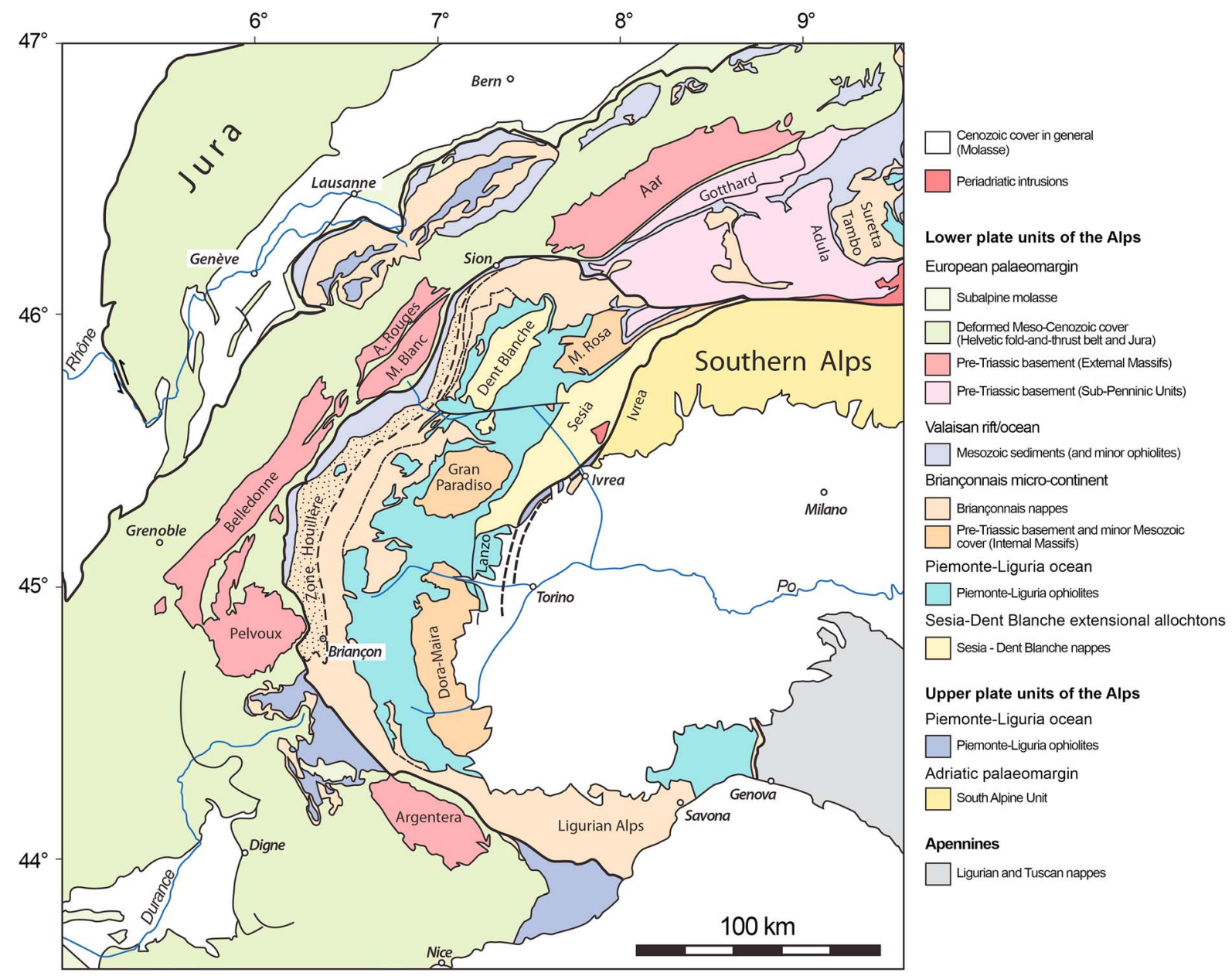

Figure 1. Schematic structural map of the Western and central Alps (modified after Schmid et al., 2004, 2017).

The first question concerns the Alpine orogenic evolution along this boundary (e.g., Butler, 1983; Ceriani \& Schmid, 2004; Ceriani et al., 2001; Fügenschuh et al., 1999), whose discussion is out of the scope of this paper. In summary, crustal-scale shortening has been achieved along the Penninic Front during the Eocene-early Oligocene (e.g., Schmid et al., 2017), followed by extensional reactivation (Sue \& Tricart, 1999). The second question relates to the paleogeographic setting of this domain before the Alpine orogeny, from the Triassic to the Cretaceous, a question that is discussed on the basis of the Mesozoic sedimentary sequences. In the south, the Subbriançonnais cover units are detached from their unknown Paleozoic basement, which is now underthrust at depth below the Briançonnais Zone. North of Moûtiers, the Valaisan Zone comprises dominantly Cretaceous flysch deposits (Antoine, 1971; Barbier \& Trümpy, 1955; Debelmas, 2001; Frisch, 1979; Jeanbourquin, 1994). Minor ophiolitic units (e.g., the Versoyen) have been recognized, but their age and tectonic setting is disputed. Some authors have proposed that the Versoyen unit is a remnant of a Carboniferous ophiolite (Masson et al., 2008; Mugnier et al., 2008; Schärer et al., 2000). Other authors interpret the Paleozoic rocks as extensional allochthons linked to the opening of a peridotite-floored, magma-poor, oceanic basin of pre-Aptian age (Beltrando et al., 2012, 2007; Loprieno et al., 2010). The third question, which is the main focus of this paper, concerns the Paleozoic history of the continental crust to both sides of this boundary. Indeed, recent models for the Variscan belt propose the existence of a large right-lateral strike-slip fault, of Late Carboniferous-Early Permian age, presently located immediately east of the eastern border of the Helvetic domain, namely, along inner margin of the External Massifs (Figure 1), running from the Aar massif to the NE to the Belledonne massif in the SW (e.g., Arthaud \& Matte, 1977; Carosi et al., 2012; Corsini \& Rolland, 2009; Duchesne et al., 2013; 
Faure et al., 2014; Guillot \& Ménot, 2009; Guillot et al., 2009; Matte, 2001; Padovano et al., 2012). This shear zone has been called the External Crystalline Massifs Shear Zone (Guillot et al., 2009) or the East Variscan Shear Zone (EVSZ) (Padovano et al., 2012, 2014). The latter name will be retained in the following. According to Guillot et al. (2009), the length of the EVSZ is of a minimum of $600 \mathrm{~km}$, and offset of Variscan suture zones across the fault system may be of the order of $300 \mathrm{~km}$.

Our purpose is to examine the potential consequences of this hypothetical EVSZ for the history of the preAlpine basement in the more internal units of the Alpine belt. We will therefore review the available data in order to discuss (i) how much the character of the pre-Triassic basement to both sides of the EVSZ differs, (ii) the tectonic significance of the Carboniferous basins that are found to both sides of the EVSZ, and (iii) differences in the Permian history east and west of the EVSZ. This review will shed light on the role of basement inheritance during the future localization of the Valaisan Basin and by consequence on the first-order distinction between Helvetic and Penninic units during the Alpine orogeny.

\section{Geological Setting}

In the Western Alps (Figure 1), opening of the Piemonte-Liguria and Valaisan Oceans during the Mesozoic led to the breakup of continental crust that was structured at the end of the Paleozoic during a major pre-Alpine orogenic event (the Variscan orogen). After Alpine orogeny, the pre-Triassic basement is now found in different tectonic units, stacked on top of each other during the Alpine orogeny. The Helvetic Zone represents the former European paleomargin, separated from the Briançonnais microcontinent by the Valaisan Ocean. The Sesia-Dent Blanche nappes comprise another piece of continental crust, generally considered of Adriatic derivation, thrusted on top of the ophiolitic units derived from the Piemonte-Liguria Ocean. All these continental units show relics of the pre-Triassic basement.

In the Helvetic Zone, the pre-Mesozoic basement crops out in several massifs (Figure 1), collectively named the "External Massifs" (von Raumer, 1984, 1993, 1998; von Raumer et al., 1999, 2003). From south to north, they are the Argentera (Corsini et al., 2004; Faure-Muret, 1955; Ferrara \& Malaroda, 1969; Monié \& Maluski, 1983; Musumeci \& Colombo, 2002), Pelvoux (Le Fort, 1973), Belledonne (Bordet, 1961; Bordet \& Bordet, 1963; Fernandez et al., 2002; Ménot, 1988; Vivier et al., 1987), Grandes Rousses, Aiguilles Rouges-Mont Blanc (von Raumer \& Bussy, 2004), and Aar (Berger et al., 2017) massifs. Their shape is partly due to the fact that they were tilted blocks bounded on their eastern side by Jurassic high-angle normal faults (Lemoine, 1985; Lemoine \& Trümpy, 1987; Lemoine et al., 1986, 1981). The mechanism and amount of reactivation of the Jurassic normal faults are still debated (Bellahsen et al., 2012, 2014; Gidon, 2001; Gillcrist et al., 1987). The Alpine deformation of these basement windows is generally weak and heterogeneous (Figure 2), with a gradient of deformation increasing from NW to SE (Aar-Gotthard: Berger et al., 2017; Choukroune \& Gapais, 1983; Marquer, 1990; Mont Blanc: Egli \& Mancktelow, 2013; Leloup et al., 2005; Rolland et al., 2008; Grand Châtelard: Marquer et al., 2006). The pre-Triassic basement is affected by subgreenschist- to greenschist-facies shear zones of Oligocene age (Cenki-Tok et al., 2014; Egli et al., 2016, 2017) predating the major (Miocene) phase of exhumation due to the initiation of frontal crustal ramps below the External Massifs (Boutoux et al., 2016). However, because the Alpine ductile deformation is not pervasive, the Variscan or pre-Variscan relationships between the different lithologies can be investigated and mapped.

In the part of the Penninic Zone comprising the former Briançonnais microcontinent, a pre-Triassic basement is present (i) in the external (frontal) part (Zone Houillère) (Figure 1), where Carboniferous and Permian sediments are unconformably covered by the Triassic to Eocene sediments (Lemoine et al., 1986), (ii) as basement slices in more internal units (Acceglio, Ambin, Vanoise, and Grand Saint-Bernard) having suffered a blueschist-facies deformation of Eocene age (Ganne et al., 2007), and (iii) as folded basement nappes (Monte Rosa, Gran Paradiso, and Dora-Maira) having suffered an early eclogite-facies deformation, and thrusted at a later stage onto lower-pressure units, exposed in the Money and Pinerolo windows (Figure 2) (Le Bayon \& Ballèvre, 2006; Manzotti, Poujol, \& Ballèvre, 2015, Manzotti et al., 2016). Due to the pervasive and polyphased Alpine deformation, undeformed volumes are relatively modest in size and allow only limited deductions about the large-scale structure of the Paleozoic basement.

The Paleozoic history of the Sesia-Dent Blanche nappes has been recently reviewed (e.g., Manzotti, Ballèvre, et al., 2014) and will not be reiterated here. Their pre-Mesozoic basement consists of (i) lower crustal units, displaying a high-grade (amphibolite- to granulite-facies) metamorphism (e.g., Manzotti \& Zucali, 2013) of 

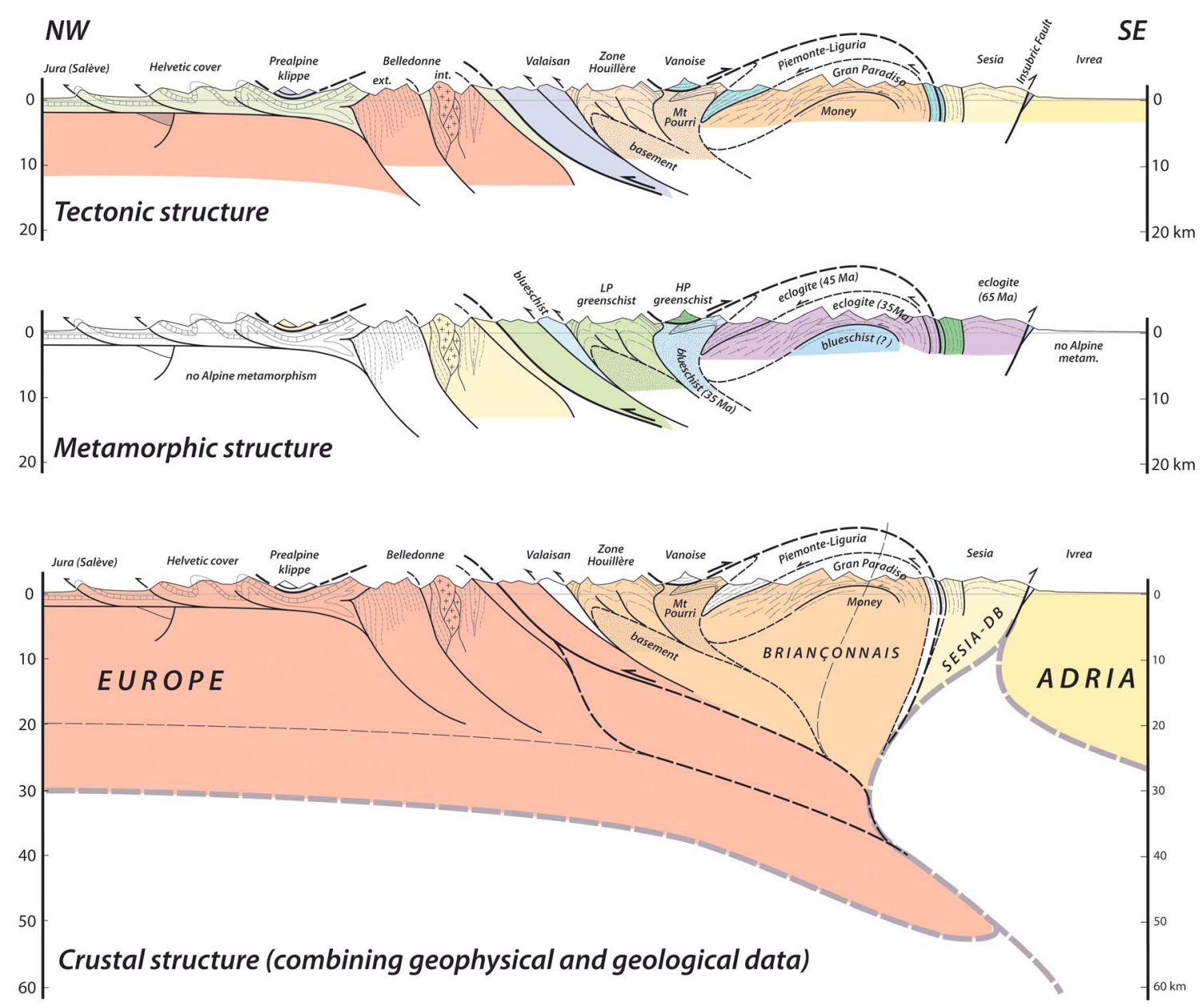

Figure 2. Schematic cross sections illustrating the key tectonic features of the Western Alps. The tectonic structure is based on Schmid et al. (2004, 2017); the metamorphic structure uses various synthetic maps (e.g., Beltrando, Compagnoni, \& Lombardo, 2010; Bousquet et al., 2012). Integration of the geophysical data in order to constrain the crustal structure of the belt is discussed by Schmid and Kissling (2000) and Schmid et al. (2004, 2017). Emphasis is put on the four main domains of continental crust, namely, Europe, Briançonnais, Sesia-Dent Blanche (DB), and Adria. LP = low pressure; HP = high pressure.

Permian age (e.g., Kunz et al., 2017), and (ii) upper crustal units, essentially made of granitoids and a few gabbros, also of Permian age (Bussy, Venturini, et al., 1998; Manzotti, Ballèvre, \& Dal Piaz, 2017; Manzotti, Rubatto, et al., 2017; Monjoie et al., 2007). The identification of pre-Permian events is a matter of debate.

At last, the South-Alpine basement (Figure 1) has been much less and only locally reworked during the Alpine orogeny, and pre-Alpine structures are well preserved. It constitutes a reference section for the crustal architecture at the end of the Permian (e.g., Henk et al., 1997; Pistone et al., 2017; Zingg, 1990) and its reworking during the Late Triassic-Jurassic rifting (Handy, 1987; Handy et al., 1999). The Ivrea-Verbano Zone displays a tilted metamorphic sequence ranging from amphibolite to granulite facies (Hunziker \& Zingg, 1980; Zingg, 1990), intruded by a huge mafic body of Early Permian age (Garuti et al., 2001; Pin, 1986; Peressini et al., 2007). Further east, the Strona-Ceneri (or Serie dei Laghi) Zone essentially consists of Early Paleozoic protoliths, now converted into amphibolite-facies orthogneisses and paragneisses (Zurbriggen et al., 1997). An Early Paleozoic age has been argued for this deformation event (Franz \& Romer, 2007; Zurbriggen, 2015), whose upper age limit is bounded by the intrusions of nearly undeformed granitoids of Permian age (Bakos et al., 1990; Klötzli et al., 2014; Pinarelli et al., 1988; Pinarelli \& Boriani, 2007; Quick et al., 2009).

\section{Method}

Our analysis will proceed in three steps. First, we will make a review of the geology of the pre-Carboniferous basement, based on an extensive search through numerous publications, complementing the data set 
already published (Manzotti, Poujol, \& Ballèvre, 2015). Rather than emphasizing models, we will carefully report the available data and evaluate the isotopic ages where available (Tables S1 to S4 in the supporting information). Second, the geology of the Carboniferous basins still preserved in the Alpine belt has been recently complemented by newly acquired data on the detrital zircons from five localities, namely, two in the Money window (Manzotti, Poujol, \& Ballèvre, 2015), two from the Pinerolo window, and one from the Zone Houillère in Briançon (Manzotti et al., 2016). Third, the distribution and age of the Permian magmatism (Tables S5 to S7) and sedimentation will be assessed with the same geographic coverage.

A short note on the vocabulary is necessary, because some difficulties may appear when using terms such as Caledonian, Variscan, late Variscan, or post-Variscan for qualifying an age range. An Ordovician age is contemporaneous of the Caledonian orogeny in its type area but does not necessarily imply a genetic link with this orogeny. For this reason, the word Caledonian will not be used in this study to avoid confusion between timing and orogenesis. Similarly, a Carboniferous age may generally reflect an event during the Variscan orogeny but not necessarily inside the Variscan belt (we do not know a priori the location of the boundaries of the Carboniferous Variscan belt inside the Present Alpine belt). The words late Variscan, or post-Variscan, will not be used when constructing our database, because they either frequently reflect vague assumptions about the age of the "end" of the Variscan orogeny or have genetic meanings (like the transition from crustal-scale shortening to mountain collapse, whatever its exact mechanism might be).

\section{The Pre-Carboniferous Protoliths and Their Metamorphic Evolution}

\subsection{Pre-Triassic Basement in the External Massifs}

The oldest recognizable sequences in the pre-Alpine basement from the Helvetic Zone are CambroOrdovician magmatic rocks (Table S1), belonging to three kinds of associations, namely, (i) ophiolite complexes, best known in the SW part of the Belledonne massif (Chamrousse Complex: Bodinier et al., 1981; Den Tex, 1950; Guillot et al., 1992; Ménot et al., 1988; Pin \& Carme, 1987), (ii) bimodal suites, and (iii) large, now strongly deformed, granitic orthogneisses (Bussy et al., 2011). Deformation and metamorphism have variably affected the Cambro-Ordovician protoliths. An eclogite-facies (or high-pressure (HP) granulite-facies) event is recorded in mafic bodies from the Argentera (Colombo et al., 1994; Ferrando et al., 2008; Latouche \& Bogdanoff, 1987), Belledonne (Paquette, Chopin, \& Peucat, 1989; Paquette, Ménot, \& Peucat, 1989), and Aiguilles Rouges (Liégeois \& Duchesne, 1981). The age of the HP metamorphism (Table S3) is still rather uncertain and has long been thought as Ordovician, by reference to the Gotthard Nappe (Abrecht et al., 1991; Abrecht \& Biino, 1994; Biino, 1994, 1997; Berger et al., 2017; Gebauer, 1990, 1993; Gebauer et al., 1988; Oberli et al., 1994). However, robust evidence for interpreting Ordovician dates as recording the age of the HP event is lacking. In the Argentera massif, recent data suggest a Carboniferous age (330 Ma) for the HP event (Rubatto et al., 2001, 2010). The metamorphic evolution then proceeds toward lower pressure, with extensive development of partial melting in appropriate lithologies (Bussy et al., 2000; Genier et al., 2008; Marshall et al., 1997; Schulz \& von Raumer, 2011; von Raumer, 1983, 1984).

Structural and petrological data from the External Massifs allow to distinguish three main structural domains (Figure 3). Domain I (western Belledonne) is known in the western part of the Belledonne massif, from la Mure in the south to Megève in the north (Figure 3). It consists of medium-grade schists deriving from a thick sequence of deep-sea, turbiditic, sediments of unknown age (Late Neoproterozoic to Early Paleozoic?). Carboniferous granitoid intrusions are absent in this domain. Domain II is recognized in the southern part of the Belledonne massif (Chamrousse-Taillefer) and the western and southwestern parts of the Pelvoux massif (Figure 3). It is characterized by a pre-Alpine nappe stack, whose uppermost unit (the Cambro-Ordovician Chamrousse ophiolite) was thrusted over the late Devonian/Early Carboniferous Rioupéroux-Livet bimodal suite. Domain II is also characterized by the presence of a thick sequence of metaconglomerates (Le Fort, 1964, 1973), of probable Visean age, and unconformably overlying older rocks (Fréville et al., 2015). Like in domain I, Carboniferous granitoid intrusions are absent in domain II.

Domain III represents the largest part of the External Massifs (Figure 3) and includes the Argentera massif, most of the Pelvoux massif, the Grandes Rousses, the eastern, internal part of Belledonne, and the Aiguilles Rouges-Mont Blanc massifs. In this domain, eclogite relics became overprinted during amphibolite-facies metamorphism, culminating with partial melting of metasedimentary as well as metaigneous protoliths. Several generations of granitic rocks are found, with an earlier Mg-suite followed by a younger Mg-Fe or 


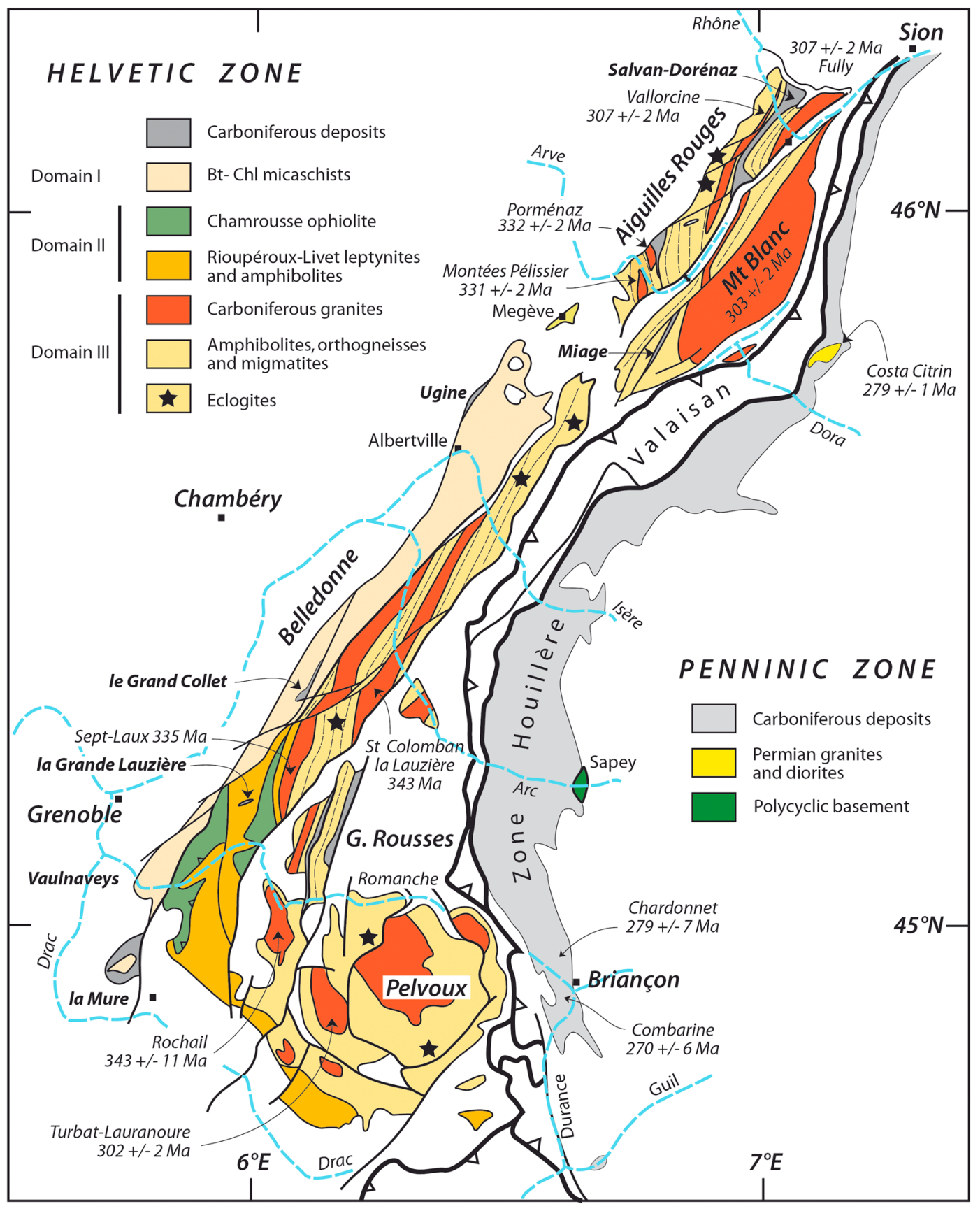

Figure 3. Geological map of the pre-Triassic basement in the External Massifs, Western Alps (modified from the Geological Map of France at $1: 10^{6}$ ). Sources for the ages of the granitoids are given in the text. Note the small size of the Late Carboniferous basins in the Helvetic Zone compared to the Zone Houillère in the Penninic Zone, a feature that is fully discussed in the text.

Fe suite (Bussien Grosjean et al., 2017; Bussy \& von Raumer, 1994; Bussy \& Hernandez, 1997; Bussy et al., 2000; Bussy, Delitroz, et al., 1998; Debon et al., 1994, 1998; Debon \& Lemmet, 1999; Guerrot \& Debon, 2000). The same magmatic history may be seen further east in the Aar massif (Berger et al., 2017; Schaltegger, 1990, 1993, 1994; Schaltegger \& Corfu, 1992; Schaltegger \& von Quadt, 1990).

\subsection{Pre-Alpine Basement of the Penninic Zone}

In the Penninic Zone, the pre-Triassic basement displays few relics of pre-Alpine metamorphic minerals and rocks. 


\subsubsection{External Briançonnais}

The famous (and controversial) thin slices of the Sapey gneisses, typically located at the eastern margin of the Zone Houillère, were long thought to display evidence for Permian metamorphism and metasomatism (Ellenberger, 1958, 1966). By now they are interpreted as polycyclic basement (basement affected by both pre-Alpine and Alpine metamorphism) because (i) some paragneisses contain garnet, staurolite, and kyanite relics (Bertrand et al., 1998; Détraz \& Loubat, 1984) and (ii) U-Pb studies of zircons from orthogneisses reveal protolith ages older than $360 \mathrm{Ma}$ (Bertrand et al., 1998). Consequently, the Sapey gneiss could either represent the basement upon which the Carboniferous sediments of the Zone Houillère (making up most of the pre-Triassic formations of the external Briançonnais) were deposited or, alternatively, mylonitized slices of the more internal Ruitor-type polycyclic basement rocks aligned along a major Alpine thrust on top of the Zone Houillère.

\subsubsection{Internal Briançonnais}

In a more internal position several outcrops of presumed pre-Triassic rocks do occur. These are briefly described from south to north.

1. In the Ligurian Alps, a few remnants of a polycyclic basement have been recognized, including eclogitefacies rocks (Cortesogno et al., 1997; Gaggero et al., 2004; Giacomini et al., 2007; Messiga et al., 1992).

2. In the Acceglio Zone, a polycyclic basement has been recognized in very restricted occurrences (e.g., north of the Pelvo d'Elva), consisting of micaschists with garnet and biotite relics (Gidon et al., 1994; Michard, 1959).

3. In the Ambin massif, two main groups (i.e., the Clarea Group and the Ambin Group) have been distinguished (e.g., Gay, 1970; Lorenzoni, 1965; Michel, 1956). The polycyclic character in the Clarea Group has been recognized on the basis of the presence of muscovite, biotite, garnet, and possible sillimanite and staurolite pseudomorphs (e.g., Bocquet, 1974; Borghi et al., 1999; Gay, 1972). Later studies have pointed out the occurrence of multistage garnets in muscovite- and biotite-bearing rocks (Ganne et al., 2003). No quantitative estimation of the pressure-temperature (P-T) conditions of the pre-Alpine metamorphism has been made, but the observed relict assemblages suggest medium-pressure amphibolite facies conditions. Preservation of growth zoning in the first generation of garnet (see Ganne et al., 2003, Figure 3 ) is also consistent with a medium temperature. Geochronological work has shown that some biotite and muscovite provided ages at 340-350 Ma, interpreted as recording the timing of the amphibolite-facies metamorphism (Monié, 1990). In the Ambin Group, the metarhyolitic rocks interbedded with the micaschists have provided ages about $500 \mathrm{Ma}$ (Bertrand, Pidgeon, et al., 2000), disclosing the hypothesis of a Permian age for this Group. The Ambin Group may be considered as a piece of Early Paleozoic material that escaped Variscan metamorphism and has been thrusted over the Clarea Group during the Alpine orogeny (Mosca et al., 2008).

4. The Southern Vanoise (=Arpont-Chasseforêt) massif is made of micaschists, similar to those of the Clarea Group in the Ambin Massif, intruded by an Ordovician granitoid (Bertrand \& Leterrier, 1997). Evidence for polycyclism in these micaschists is restricted to the occurrence of garnet, interpreted as relics of pre-Alpine age (Bocquet, 1974).

5. The Northern Vanoise (=Bellecôte-Mont Pourri) massif is made of mafic and felsic metavolcanics, and interbedded black schists, previously assumed to be Carboniferous in age because of their monocyclic character (Desmons \& Fabre, 1988; Ellenberger, 1958, 1966; Guillot et al., 1986). However, the schists are intruded by granophyric epiplutonic rocks (Beucler et al., 2000), which have provided a late Cambrian age (Guillot et al., 1991). It is therefore considered that the Early Paleozoic basement from the Bellecôte-Mt Pourri massif did not suffer significant Variscan deformation and metamorphism.

6. The Grand Saint Bernard nappe crops out from the Aosta valley to the Simplon area and is subdivided into several units following detailed mapping (Burri, 1983a, 1983b; Gouffon, 1993; Gouffon \& Burri, 1997; Sartori et al., 2006). Polycyclism is recorded in some of these units, here described from bottom to top.

a. South of the Aosta valley, and from there to the col du Grand Saint Bernard and further north, the Ruitor unit displays various high-grade metamorphic rocks (Caby, 1968; Fabre, 1961; Laduron \& Desmons, 1981), the pre-Alpine age being ascertained because pre-Alpine granitic dykes cut across the high-temperature foliation. Four samples of orthogneisses have provided Ordovician protolith ages (Guillot et al., 2002). Amphibolite-facies parageneses in metapelites are best preserved in the Mont Mort metapelites (Burri, 1983a, 1983b; Giorgis et al., 1999; Thélin, 1992), where they display 
muscovite-garnet-staurolite-biotite assemblages. U-Pb data on two monazite fractions from the Mont Mort metapelites indicate an age of $330 \pm 2 \mathrm{Ma}$, interpreted as recording the peak metamorphic event (Bussy, Sartori, \& Thélin, 1996), consistent with Ar/Ar ages of muscovite at around 330-300 Ma (Giorgis et al., 1999).

b. In the Siviez-Mischabel nappe (Scheiber et al., 2014), among other bodies, the Randa orthogneiss has been dated at 270 Ma (Bussy, Derron, et al., 1996; Thélin, 1987). Eclogites are discontinuously found as lenses in amphibolites (Eisele et al., 1997; Rahn, 1991; Sartori, 1990; Thélin et al., 1990). The age of the eclogites is not known, although most authors have assumed, by comparison with the Gotthard Nappe, that they are Ordovician ( 470 Ma). Ar-Ar data on muscovite have been attributed to a metamorphic event of Carboniferous age (Markley et al., 1998).

c. In the Mont Fort nappe, the Métailler Formation is thought to represent the pre-Alpine basement. This is supported by geochronological data, suggesting magma emplacement at $460 \mathrm{Ma}$ (Gauthiez et al., 2011). The metamorphic history displays the classic blueschist- to greenschist-facies evolution that is commonly observed in other Alpine rocks and is therefore assumed to be monocyclic and of Alpine age.

4.2.3. Briançonnais of the Internal Massifs

The Internal Massifs (Monte Rosa, Gran Paradiso, and Dora-Maira) are windows below the ophiolitic units and are essentially made of pre-Triassic rocks, their Mesozoic cover having been detached at an early stage of the Alpine orogeny. Although the Internal Massifs suffered an eclogite-facies overprint during the Alpine orogeny, polycyclic rocks have been identified either in low-strain volumes or using mineralogical relics like garnet, muscovite, and tourmaline in highly strained rocks.

In the Monte Rosa nappe, relics of pre-Alpine assemblages are quite common in meter- to kilometer-sized low-strain volumes (Bearth, 1952; Dal Piaz, 1966, 1971, 2001; Dal Piaz \& Lombardo, 1986). Relict assemblages include quartz-plagioclase-Kfs-garnet-biotite-sillimanite and plagioclase-muscovite-garnet-biotite-sillimanite in paragneisses and a few brown hornblende in metabasites. The last stages of the regional metamorphism are recorded by the late development of cordierite-rich partial melts. P-T conditions of the pre-Alpine metamorphism have not been investigated in detail, but mineral assemblages are consistent with amphibolitefacies or high-grade amphibolite facies conditions. The regional metamorphism and partial melting predates an extensive set of discordant granitic dykes and plutons, once thought to be Late Carboniferous in age (Frey et al., 1976; Hunziker, 1970) but most probably of Permian age (see below).

In the Gran Paradiso nappe (Borghi \& Sandrone, 1995; Compagnoni et al., 1974; Le Bayon \& Ballèvre, 2006), relics of pre-Alpine structures and minerals have been described in two different settings. First, a few hornfelses have been mapped close to undeformed intrusive contacts with pre-Alpine granitoids (Bertrand, 1968; Callegari et al., 1969; Compagnoni \& Prato, 1969). Second, mineral relics like muscovite, garnet, and tourmaline have been found in some micaschists, away from intrusive contact or orthogneisses. These are therefore attributed to a regional metamorphism predating the contact metamorphism. Estimated P-T conditions for the pre-Alpine metamorphism, based on the chemistry of the garnet cores and calculated using a pseudosection approach, are at around $6 \mathrm{kbar}$ to $620^{\circ} \mathrm{C}$ (Le Bayon et al., 2006). For the appropriate bulk-rock chemistry, the observed relict garnet compositions fall into a muscovite-staurolite-biotite assemblage, suggesting that the chloritoid aggregates now observed in the studied samples derive from pre-Alpine staurolite. Once again, the pre-Alpine garnet preserves its growth zoning, compatible with medium-pressure amphibolite facies conditions. As a whole, these data suggest that the piece of continental crust now present in the Gran Paradiso massif underwent a pre-Alpine history recording decompression (i.e., exhumation) between regional metamorphism (undated) and the intrusion of the Permian granitoids.

In the Dora-Maira nappe, pre-Alpine relics have been identified in several localities (Michard, 1967; Vialon, 1966) but rarely studied in detail. One of the most common relics is provided by multistage garnets (Borghi et al., 1985; Matsumoto \& Hirajima, 2000; Sandrone \& Borghi, 1992). More complete parageneses in low-strain domains are very rare and only two examples are known. First, in the southern Dora-Maira massif, rare paragneisses from the ultrahigh-pressure Brossasco-Isasca unit still preserve pre-Alpine garnet, biotite, and sillimanite (with quartz and pseudomorphs after plagioclase) (Compagnoni \& Rolfo, 2003). These rocks are cut by granitic dykes and plutons, whose marginal facies contain them as abundant xenoliths. Second, in the northern Dora-Maira massif, the micaschists from the Punta Muret (Bouffette et al., 1993; Cadoppi, 1990; Vialon, 1966) preserve garnet, biotite, and sillimanite as pre-Alpine relics, for which P-T conditions have been estimated at $4-7 \mathrm{kbar}, 650-700^{\circ} \mathrm{C}$. 


\subsection{Overview of the Metamorphic Evolution in the Pre-Alpine Basement}

The pre-Alpine metamorphic evolution of the basements now involved in the Alpine belt (Figure 4) displays the following characteristics:

1. The External Massifs occasionally preserve eclogite relics in high-grade amphibolite facies rocks (migmatites), dated in a few cases at around $330 \mathrm{Ma}$ (Table S2). This evolution is closely comparable to that described in the Massif Central, the Vosges, and the Schwarzwald (Black Forest) (e.g., von Raumer, 1993), only to cite the closest occurrences outside the Alpine belt.

2. In the Briançonnais Zone, some but not all units are largely devoid of evidence for metamorphism and deformation during the Variscan orogeny (Ambin Group and Southern and Northern Vanoise). These formations do not show, or preserve, relics of a pre-Alpine metamorphism, either because it has taken place at low grade or because these rocks are, in fact, younger than the Variscan orogeny. However, geochronogical data on interbedded volcanics or intrusive bodies have shown that these igneous rocks derive from protoliths of Cambro-Ordovician age (Table S1), and this implies that the Variscan metamorphism is indeed either lacking or of very low grade in these units.

3. Other pre-Triassic basement complexes in the Briançonnais Zone, such as the Ruitor and Siviez-Mischabel units, are polycyclic in that they record pre-Alpine amphibolite facies conditions, the highest metamorphic grade being defined by garnet-staurolite-biotite ( \pm sillimanite) assemblages in the Ruitor, dated at $330 \mathrm{Ma}$, hence as Carboniferous (Bussy, Sartori, \& Thélin, 1996). More problematic is the occurrence of relict eclogites in the Siviez-Mischabel nappe, whose age remains unknown.

\section{The Carboniferous (Pennsylvanian) Basins}

\subsection{Carboniferous Basins in the Helvetic Zone}

Carboniferous basins are known outside the Alpine belt, e.g. in Provence (Basso, 1987; Bordet, 1951), as well as in all External Massifs (Figure 3), from the Argentera to the Aar Massif (Haudour \& Sarrot-Reynauld, 1964). Some of them are quite well preserved, because they show no internal strain (Fernandez et al., 2002). Others have suffered some Alpine deformation, from moderate folding in the la Mure basin to folding with schistosity like the Salvan-Dorénaz Basin (Badertscher \& Burkhard, 1998; Pilloud, 1991). Sedimentological studies in these basins have provided evidence for syntectonic sedimentation derived from a local, proximal source (Capuzzo \& Wetzel, 2004; Capuzzo et al., 2003; Niklaus \& Wetzel, 1996). Some of these basins may contain minor amounts of acid volcanic flows or aerial ash falls (Salvan-Dorénaz). However, the easternmost Carboniferous basin, in the Grandes Rousses, is distinguished from the other basins by the occurrence of huge, thick lavas flows, and pyroclastics interbedded into the coal-bearing sediments (Banzet et al., 1984, 1985).

The coal-bearing basins from the External Massifs have provided paleontogical evidence for a late Westphalian D-Stephanian age (Figure 4 and Table S8), for example, in the Argentera massif (Corsin \& Faure-Muret, 1946; Faure-Muret, 1955; Haudour et al., 1958), in the Belledonne massif (la Mure: Bouroz \& Corsin, 1950; Martin, 1960; Vallois \& Belleserre, 2015; Vaulnaveys: Gignoux \& Moret, 1952; la Lauzière: Gignoux \& Moret, 1952), the Grandes Rousses (Bellet, 1933; Bordet \& Corsin, 1951), in the Aiguilles Rouges (Héry-syur-Ugine: Brousmiche Delcambre et al., 1999; Porménaz: Bertrand, 1926; Laurent, 1965, 1968; Lox \& Bellière, 1993; Salvan-Dorénaz: Jongmans, 1950; Brousmiche Delcambre et al., 1999) and in the Aar Massif (Brousmiche-Delcambre \& Menkveld-Gfeller, 2007; Jongmans, 1950, 1960; Ledermann, 1964). Although a revision of the paleofloras in the light of modern biostratigraphy would be welcome, it is worth emphasizing that geochronological data on interbedded volcanics are consistent with the paleontological data in the Salvan-Dorénaz basin (Capuzzo \& Bussy, 2000).

Three types of relations are known between the Carboniferous basins and their metamorphic-granitic substratum.

1. The Carboniferous sediments along the western border of the Belledonne massif rest unconformably on top of the micaschists of domain I (Figure 3). The sedimentary sequences are in most cases undeformed, tilted, or gently folded (e.g., Goguel, 1956). The Carboniferous sediments are presently poorly and discontinuously outcropping, but they may have been much more extended in the geological past, that is, before erosion following the Alpine orogeny. 

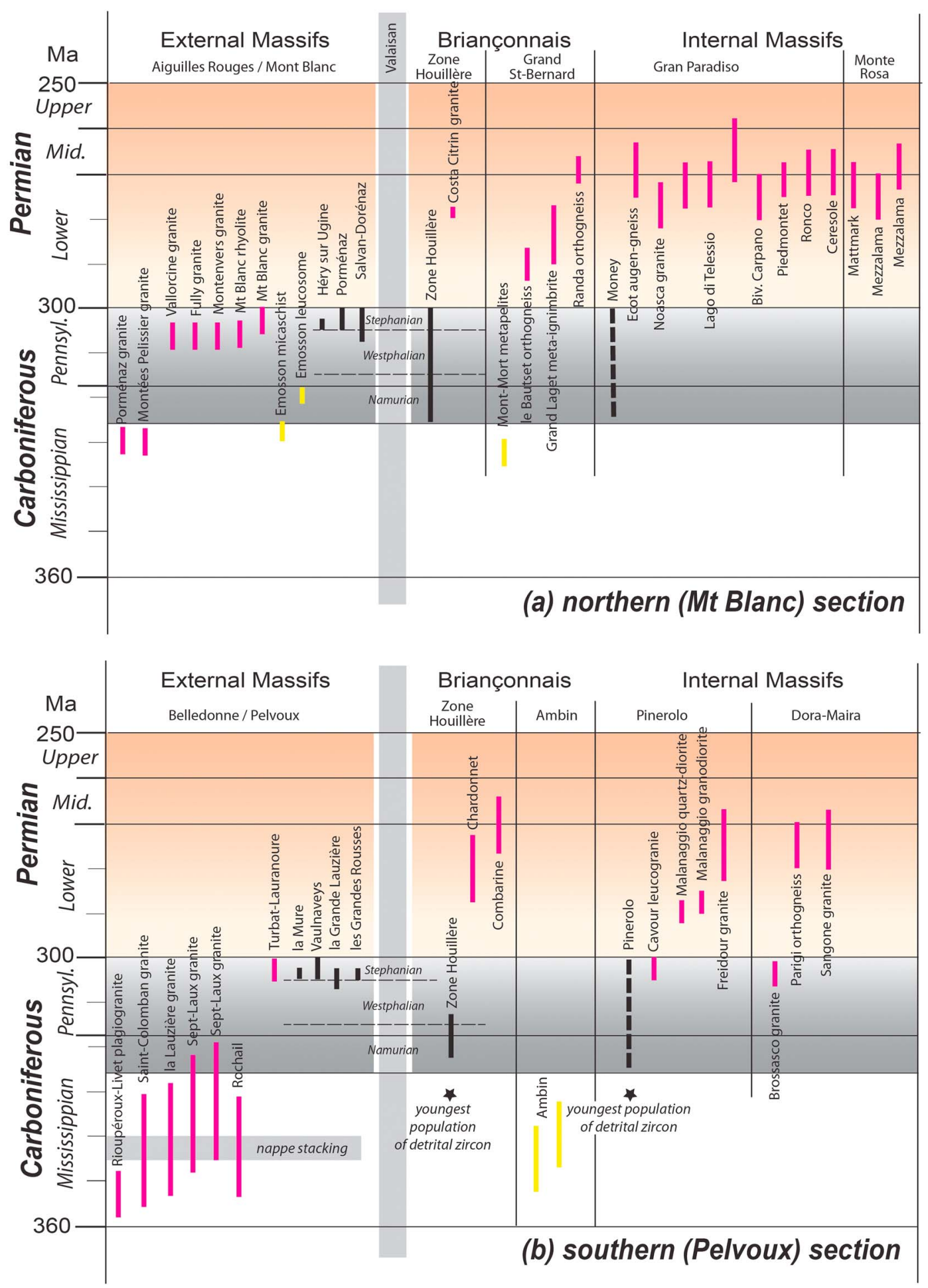

Figure 4. A summary of the age data along two traverses in the Western Alps, a northern traverse across the Mont Blanc (a), and a southern section across the Pelvoux (b). Red bars refer to ages in magmatic (mostly granitic) rocks, yellow bars refer to metamorphic ages, and black lines denotes the range of sedimentation as deduced from paleontological data. The dominance of Carboniferous or Permian magmatism in the Helvetic and Penninic Zones (respectively) is clearly depicted. Note also the age difference in the coal-bearing basins from the Helvetic (Gzhelian) and Penninic (Serpukhovian to Bashkirian) Zones. Sources of data are reported in Tables S1 to S8. 
2. In the western part of domain II (Figure 3), Carboniferous sediments are lacking, the Triassic rocks resting directly and unconformably on top of the pre-Alpine nappe stack (e.g., la Croix de Chamrousse: Den Tex, 1950). In the eastern part of domain III, the Carboniferous sediments are unconformably resting on top of strongly metamorphosed rocks (la Grande Lauzière and la Grande Lance). The sediments still present today exhibit a subhorizontal or shallow dipping attitude. High-angle normal faults bounding the outcrop and cutting downward through the basement have been assumed to represent synsedimentary faults (Hernandez et al., 2002). Numerous pebbles from the Cambro-Ordovician Chamrousse Complex are found in the Grande Lauzière conglomerates (Den Tex, 1950; Gignoux \& Moret, 1952; Moret, 1945), which indicates that part of domain II was uplifting during the Stephanian with respect to the adjacent domain.

3. In domain III, Carboniferous sediments are pinched into "synclines" that most commonly result from the Alpine inversion of Carboniferous half-grabens (Figure 3). In such cases, the Carboniferous sediments may be severely folded and cleaved (Grandes Rousses and Porménaz: Dobmeier \& von Raumer, 1995; SalvanDorénaz: Badertscher \& Burkhard, 1998; Pilloud, 1991; Miage: Franchi \& Stella, 1903; Vernet, 1969). The unconformity at the base of the Carboniferous is still observable, and the sediments rest either on Visean granites (Porménaz) or on (presumably Visean) metamorphic rocks (Salvan-Dorénaz). The bounding faults of the half-grabens may be identified but have been reworked during the Alpine orogeny (Porménaz Fault: Dobmeier \& von Raumer, 1995; Miéville Shear Zone: Oulianoff, 1929).

\subsection{Carboniferous Basins in the Penninic Zone}

\subsubsection{The Zone Houillère}

The easternmost, frontal part of the Briançonnais zone is marked by a continuous outcrop of terrigenous coal-bearing sediments (the Zone Houillère) (Figure 3), which extends from the Rhône valley (Switzerland) to the Briançon area (France), that is, along a length of about 200 km (Fabre, 1961; Fabre et al., 1982; Feys, 1963; Feys et al., 1964; Greber, 1965; Peola, 1903; Pussenot, 1930). Further south, discontinuous outcrops of Carboniferous sediments in the same structural position are found in the Guil and Ubaye (Gidon, 1962) valleys (France) and then in the Ligurian Alps (Italy) (Bloch, 1966; Cortesogno et al., 1988, 1998; Portis, 1887; Pšenička et al., 2017; Squinabol, 1887; Vanossi, 1971). The width of this Zone Houillère does not exceed a few kilometers (a maximum of $16 \mathrm{~km}$ is reported in the Maurienne valley) and is reduced to a few hundred meters along the Rhône valley. As usual in continental deposits, key stratigraphic markers are lacking for large-scale correlations. However, superposed lithological sequences have been distinguished and dated using paleofloras (Corsin, 1950; Greber, 1965; Schade et al., 1985), indicating continuous sedimentation from the Namurian to the Stephanian. However, revision of the paleobotanical data denies the presence of floras younger than the Westphalian A (Brousmiche Delcambre et al., 1995, 1996; Brousmiche Delcambre, Coquel, \& Mercier, 1997; Brousmiche Delcambre, Mercier, \& Coquel, 1997): sedimentation seems to be confined to the Namurian-Westphalian A, that is, to the time interval 325-315 Ma (Figure 4 and Table S8).

Sedimentological studies (Mercier \& Beaudoin, 1984, 1987) provide evidence for changing depositional settings through time, from fluviatile to lacustrine, and for a global drainage pattern from south to north, that is, almost parallel to the axis of the present-day Zone Houillère. This indicates that the Carboniferous basin was elongated close to its present-day axis (although displaced to the WNW during the Alpine orogeny). Detrital geochronology of the Zone Houillère (Manzotti et al., 2016) shows a strong dominance of zircon grains derived from magmatic sources whose age cluster at around $340 \mathrm{Ma}$. These detrital grains cannot have been provided by the Penninic Zone, which is devoid of Carboniferous granitoids. Hence, their source probably has to be located in the future Helvetic Zone, further south in the Maures massif (Oliot et al., 2015), or in CorsicaSardinia (Faure et al., 2014; Rossi et al., 2009), all areas where Carboniferous granitoids are abundant.

5.2.2. The Pinerolo and Money Windows in the Internal Massifs

In the Dora-Maira Massif, the Pinerolo window is essentially made of fine- to coarse-grained terrigenous rocks whose gray to black colour is due to the presence of abundant graphite. This kind of lithological association (coarse-grained detrital material in vertically and laterally very variable sequences, associated to a large amount of graphitic material) is a unique feature in the European geological history, characterizing the Upper Carboniferous. For this reason, the Pinerolo sequence has been considered Carboniferous in age since a long time (Argand, 1911; Michard, 1967; Novarese, 1895, 1896; Vialon, 1966).

In the Gran Paradiso Massif, two types of sequences have been found in the Money window (Manzotti \& Ballèvre, 2013; Manzotti, Le Carlier de Veslud, et al., 2014; Manzotti, Poujol, \& Ballèvre, 2015; Manzotti, Pitra, et al., 2015). First, a polygenic sequence is characterized by the abundance of graphite, and laterally 
discontinuous layers of (meta) conglomerates set in finer-grained quartz-rich micaschists. This sequence is very similar to the sequences observed in the Pinerolo window. Second, a monogenic sequence is dominated by quartz-rich metaconglomerates, with a few interbedded layers of graphite-bearing micaschists.

Detrital geochronology of the Money (Manzotti, Poujol, \& Ballèvre, 2015) and Pinerolo (Manzotti et al., 2016) has confirmed the Carboniferous age of the metasediments and has provided evidence for contrasting sources. The Pinerolo metasediments contain a large amount of zircon grains derived from magmatic sources whose age cluster at around $330 \mathrm{Ma}$. Together with older groups clustering at 400 and $600 \mathrm{Ma}$, they are very similar to those of the Zone Houillère, suggesting similar sources for the detrital material. By contrast, the Money metasediments have no Carboniferous zircons and are dominated by grains reworked from sources about 450-460 Ma old.

\section{Permian Magmatism and Sedimentation}

\subsection{Permian Magmatism and Sedimentation in the Helvetic Zone}

As pointed out by Bussy et al. (2001), "Permian events are hardly recorded in the External Massifs." Indeed, Permian magmatism (strictly speaking younger than $295 \mathrm{Ma}$ ) is almost absent in the External Massifs (Figure 5 and Tables S5 and S6). In a few cases (e.g., the Allevard sandstones, in the eastern part of the Belledonne massif; Barféty et al., 1984; Corsin \& Tobi, 1954; Liard, 1970), some red to green sediments associated with or stratigraphically overlying Late Carboniferous black sediments have provided paleofloras indicating transitional Carboniferous to Permian ages ("Autunian"; Pellenard et al., 2017). Significant Permian sedimentation is only found south and southeast of the Argentera massif (e.g., Barrot dome; Faure-Muret, 1955).

\subsection{Permian Magmatism and Sedimentation in the Zone Houillère}

In the Zone Houillère, the magmatic activity is recorded by numerous sills and stocks that intrude the Carboniferous sediments (Cannic et al., 2002; Ouazzani \& Lapierre, 1986; Ouazzani et al., 1987; Piantone, 1980; Termier, 1901, 1903). A few of them have been dated as Early Permian by using the Ar-Ar method on amphibole (Cannic et al., 2002) (Figure 5). Intermediate to acid volcanic rocks ("andesites" and "dacites") are frequently observed below the Early Triassic quartzites (e.g., in the Ubaye and Guil valleys) and therefore are assumed to be of Permian age. Further evidence for (Early to Middle) Permian volcanism is also found in the numerous pebbles of reddish acid volcanics (rhyolites) found in the conglomerates from the "Verrucano" facies, largely present all over the Briançonnais Zone at the base of (and succeeded in continuity by) the Early Triassic quartzites (Fabre, 1961; Ellenberger, 1958, 1966). All this testifies a widespread magmatic event of Permian age in the Zone Houillère, in strong contrast with the Helvetic basement. Further north, the Zone Houillère sediments are intruded by a laccolith of rhyolitic-dacitic chemistry (Caby, 1974). Its age, previously constrained at around $325 \mathrm{Ma}$ based on $\mathrm{U}-\mathrm{Pb}$ ages on zircon (isotope dilution-thermal ionization mass spectrometry: Bertrand et al., 1998), is at odds with the intrusive relationships of the magmatic body. This age has been recently revised and is now established at around $280 \mathrm{Ma}$ (laser ablation-inductively coupled plasmamass spectrometry: Bergomi et al., 2017). In the Ligurian Alps, which represent the southernmost extension of the Zone Houillère, an abundant Permian magmatism is also documented (e.g., Cortesogno et al., 1998; Dallagiovana et al., 2009; Maino et al., 2012).

The internal units from the Briançonnais Zone (Acceglio and Ambin) are distinguished by the widespread occurrence of rhyolitic lava flows and tuffs, sometimes accompanied by coarse-grained porphyroclasts of former K-feldspars, replaced first by albite then by jadeite (Lefèvre \& Michard, 1965, 1976; Michard, 1977). The relationships between the polycyclic basement and the volcanics are not known, being unexposed. Although the derivation from Permian acid volcanics is widely accepted, the precise age is not isotopically established.

\subsection{Permian Magmatism in the Internal Massifs}

The Monte Rosa, Gran Paradiso, and Dora-Maira are allochthonous units (i.e., nappes) essentially made of augen gneisses derived from porphyritic granitoids (Figure 5). The latter intruded amphibolite-facies paragneisses and minor amphibolites into which they develop a contact metamorphism (Monte Rosa; Bearth, 1952; Gran Paradiso; Compagnoni \& Prato, 1969; Gabudianu Radulescu et al., 2011). Initially considered as Late Carboniferous based on Rb/Sr measurements (Frey et al., 1976; Hunziker, 1970), the age of this major 

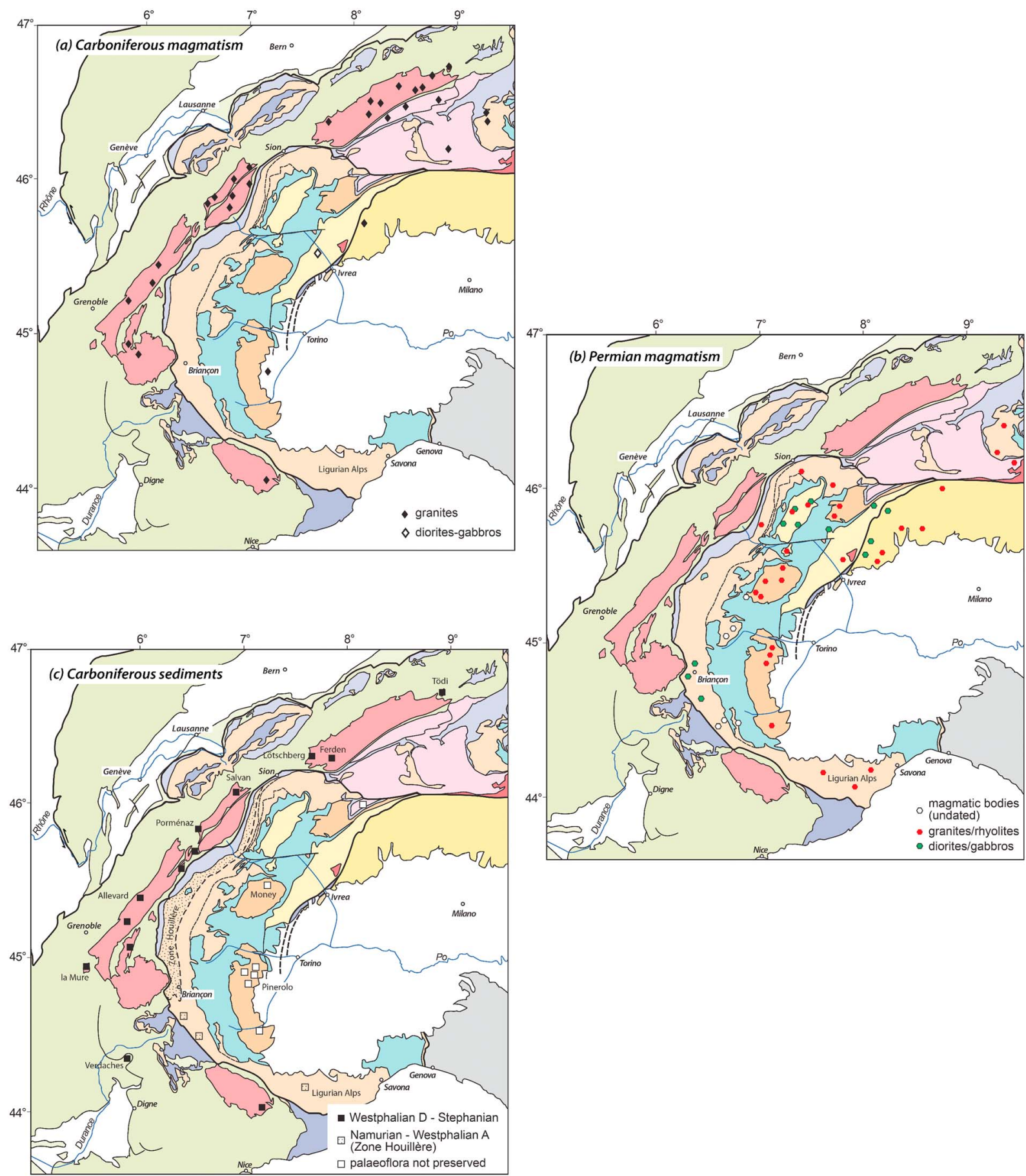

Figure 5. Distribution of the Carboniferous (a) and Permian (b) magmatism in the Western Alps. Carboniferous granites are largely distributed in the Helvetic basement, from the Argentera to the Aar massifs (only those dated are shown on the map). Note the lack of Permian magmatism in the Helvetic Zone and the widespread occurrence of Permian granites and gabbros east of the Penninic Thrust. Carboniferous sediments (c) are younger (i.e., Westphalian D-Stephanian) in the Helvetic Zone and older in the Briançonnais domain (i.e., Namurian to Westphalian A). Sources of data are reported in Tables S1 to S8.

episode of magmatism is now well established as being Permian based on U/Pb dating of zircon (Bertrand et al., 2005; Bertrand, Pidgeon, et al., 2000; Dora-Maira; Bussy \& Cadoppi, 1996; Gran Paradiso; Gebauer et al., 1997; Liati et al., 2001; Ring et al., 2005; Monte Rosa; Pawlig, 2001) (Table S6). It is remarkable that Carboniferous ages have not been obtained for the granitic protoliths in the Internal Massifs, with very few exceptions, close to the Carboniferous-Permian boundary (e.g., the Brossasco metagranite, Paquette et al., 
1999). Given the abundance of orthogneisses, this means that Carboniferous granitoids (strictly speaking older than $305 \mathrm{Ma}$ ) are most probably lacking in the pre-Triassic basement of the Internal Massifs.

\section{Discussion}

Before the Alpine orogeny, the Penninic Front was a zone of major crustal weakness, allowing, at least along its northern part, the opening of a mantle-floored basin (the Valaisan Ocean). The latter may have opened as a southward propagating rift either obliquely to the internal structure of the Variscan belt (Carboniferous in age) or reactivating a crustal-scale fault inherited from the Variscan orogeny or from its Permian dislocation. The following discussion is intended to clarify these issues.

\subsection{Large-Scale Zonation of the Variscan Belt}

The large-scale structure of the Variscan belt is still a matter of discussion, but most authors agree on three key points (Figure 7). First, the Variscan belt results from crustal stacking following resorption of one or several oceanic domains by subduction, associated with magmatic arc development during the Devonian and Early Carboniferous (e.g., Franke et al., 2017; Matte, 2001; Paquette et al., 2017; von Raumer et al., 2015). Oceanic sutures are therefore identifiable in the Variscan belt. Second, the Variscan belt is a double-vergent belt, with a (i) north vergent fold-and-thrust belt and associated foreland basin running from SW Ireland to the Harz Mountain in Germany and (ii) a north then west then south vergent thrust stack running from the Cantabrian Mountain to the Bohemian Massif. The associated foreland basin is discontinuously preserved in the core of the Cantabrian Zone on the one hand and in the Moravo-Silesian Zone on the other hand. Third, the large-scale pattern of the Variscan belt is characterized by strongly arcuate structures (variously called arcs, oroclines, virgations, and syntaxes), which were acquired at a late stage (i.e., uppermost Carboniferous to basal Permian) of its history. From west to east, these are the Iberian arc, the IberoArmorican arc, and the Bohemian arc. The Iberian arc (Martínez-Catalàn, 2011a) is out of scope of our study and will not be discussed further. The Ibero-Armorican arc is widely acknowledged and was built during the uppermost Carboniferous (305-300 Ma) (for a review, see Bard et al., 1971; Ballèvre et al., 2014). The Bohemian arc is bounded to the southeast by a transcurrent shear zone (Matte, 2001) displacing the main (southern) Variscan suture zone from Bohemia to Corsica (Corsini \& Rolland, 2009; Duchesne et al., 2013; Faure et al., 2014; Guillot \& Ménot, 2009; Padovano et al., 2012, 2014; Rossi et al., 2009). This EVSZ is now largely integrated into the Alpine belt and is therefore of a major concern for our purpose. According to this model, the northernmost part of Corsica would belong to Gondwana (Guillot et al., 2009), or Brunia (Corsini \& Rolland, 2009), or even to Armorica (Faure et al., 2014; Rossi et al., 2009). The reconstitutions made by von Raumer et al. $(2009,2013,2015)$ essentially agree with this model, although in most cases drawn at a much larger scale.

\subsection{Paleogeographic Position of the Pre-Triassic Basements Before the Alpine Orogeny}

The former location of the pre-Triassic basement complexes in the Alps with respect to each other and with respect to "stable" Europe (i.e., outside the Alpine belt) is difficult to reconstruct for the Permian paleogeography for several reasons. First, although the exact position of Iberia with respect to Europe before the midCretaceous opening of the Bay of Biscay is still open to discussion, Iberia has to be rotated clockwise by about $40^{\circ}$. Second, the Sardinia-Corsica block has to be back-rotated clockwise and aligned with the Balearic Islands and is almost coincident with the Provence coast, leaving Sardinia in front of the Maures-Tanneron massif.

7.2.1. Paleogeographic Position of the External Massifs

Structural studies have consistently shown that the External Massifs, from the Belledonne massif to the Aar massif, are displaced toward the NW during the Alpine shortening, the amount of shortening increasing from SW to NE (e.g., Bellahsen et al., 2014). Although internally deformed, the displacement of the Pelvoux and Argentera Massifs is considered as being much smaller than the other External Massifs. Accordingly, the bend in structural direction from NE-SW displayed by the Belledonne-Aiguilles Rouges-Mont Blanc Aar massif to the NW-SE orientation shown by the Pelvoux-Argentera massif is not due to the Alpine tectonics (Bellahsen et al., 2014; Lemoine et al., 1989) but was already present during the Triassic. During Jurassic extension, this bend controlled the location and orientation of normal faults and the associated sedimentary domains (e.g., Dardeau, 1984; Lemoine et al., 1989). Therefore, the now strongly arcuate Briançonnais Zone probably was much more linear before Alpine orogeny, aligned with and located north of the Sardinia- 
Corsica block (e.g., Dumont et al., 2011, 2012; Lemoine, 1985; Lemoine \& Trümpy, 1987; Lemoine et al., 1989; Schmid et al., 2004; Ziegler, 1993) or close to it (Schmid et al., 2017).

\subsubsection{Paleogeographic Position of the Internal Massifs}

The location, prior to the Alpine orogenesis, of the Internal Massifs (Monte Rosa, Gran Paradiso, and Dora-Maira) has been a matter of some debate. Do they belong to the most distal part of the Iberian (Briançonnais) paleomargin, or were they initially located west of the Valaisan Basin, in the most distal part of the European paleomargin? The classic solution, initially proposed by Argand (1911), is to consider these basement nappes as intermediate between the "nappe du Grand Saint-Bernard" and the "nappe Sesia-Dent Blanche." Argand suggested that the Nappe du Grand Saint Bernard was reappearing as a window in the Pinerolo region. Because the ophiolite bodies are thrusted over these Internal Massifs, most geologists have considered them as representing the most distal part of the lbero-Briançonnais continental margin. Other hypotheses include the one advocated by Froitzheim $(1997,2001)$, based on geometrical considerations on unfolding the nappe stack in the Monte Rosa area and supported by geochronological data according to which the peak $\mathrm{P}$ assemblages in the Monte Rosa nappe would be younger than in the classical Briançonnais basement (Gebauer, 1999; Liati \& Froitzheim, 2006). As a result, the Monte Rosa would belong to the distal part of the European margin, located west of the oceanic Valaisan Basin. Taking into account the similarities between the Monte Rosa on the one hand and the Gran Paradiso and Dora-Maira Massifs on the other hand (Argand, 1911), the above hypothesis-considering the Monte Rosa as European (i.e., external to Valaisan) (Froitzheim, 1997, 2001; Herwartz et al., 2008; Pleuger et al., 2005; Ziegler, 1989)—would need to be extended to both the Gran Paradiso and the Dora-Maira.

Increased geological knowledge of these three units during the last 25 years has confirmed that the Internal Massifs share a common history, both in terms of Alpine orogeny (not to be discussed here), but also in terms of their pre-Alpine structure. Notable features are the regional, amphibolite-facies, metamorphic rocks intruded by an extensive set of K-feldspar bearing granitoids (now mostly augen orthogneisses) of Permian age. Orthogneissic bodies of Carboniferous age are almost unknown, and very few Ordovician bodies have been recognized. This is clearly at variance with what is found in the External Massifs west of the Valaisan. Another relevant feature is provided by the windows of Carboniferous sediments found in both the Dora-Maira (Pinerolo Unit) and the Gran Paradiso (Money Unit) Massifs. These Carboniferous sediments were intruded by Permian diorites and granites, and in this respect they are similar to the Zone Houillère east of the Valaisan.

The final answer to this puzzling question could reside in the Mesozoic covers found on top of these basement units. Most of these covers are (unfortunately) absent (i.e., detached at an early stage of the Alpine orogeny) or strongly reduced due to intense deformation and metamorphism. However, they display white, mature quartzites followed by thick dolomite carbonates, then breccia-bearing calcschists, a sequence typical of the internal Briançonnais zone ("pré-Piémontais" sequences; Lemoine et al., 1986). On balance, the simplest hypothesis is to maintain the original idea of Argand and consider the Internal Massifs as deriving from the easternmost part of the Briançonnais microcontinent (Figure 6), facing the exhuming mantle of the Piemonte-Liguria ocean.

\subsection{Tectonics of the Carboniferous Sedimentary Basins}

The Carboniferous basins preserved in the Alpine belt have in common their limnic character. Based on their sedimentology and their (scarce) faunas, no marine incursion is known in any of these basins. However, they belong to two different types.

\subsubsection{The Carboniferous Basins in the Helvetic Basement}

In the Helvetic Zone, Carboniferous sediments were deposited in rather small, elongate, and narrow basins (the largest are observed in la Mure and Salvan-Dorénaz) and during a short time interval (Westphalian D (rarely) to Stephanian, i.e., Gzhelian). Sedimentological studies have shown that the source of the detrital material in these basins is always local. For example, pebbles of the Cambro-Ordovician Chamrousse Complex are found in the Grande Lauzière conglomerates, the closest Stephanian basin (Den Tex, 1950; Gignoux \& Moret, 1952). The basins opened during active tectonism, although the faults bounding the basins have not frequently been recognized. An example could be the Miéville Shear Zone, along the eastern boundary of the Vallorcine granite (Kerrick et al., 1980; Oulianoff, 1929; Steck \& Vocat, 1973), and possibly controlling sedimentation in the Salvan-Dorénaz basin. As previously noted by many authors (e.g., Greber, 1965), 


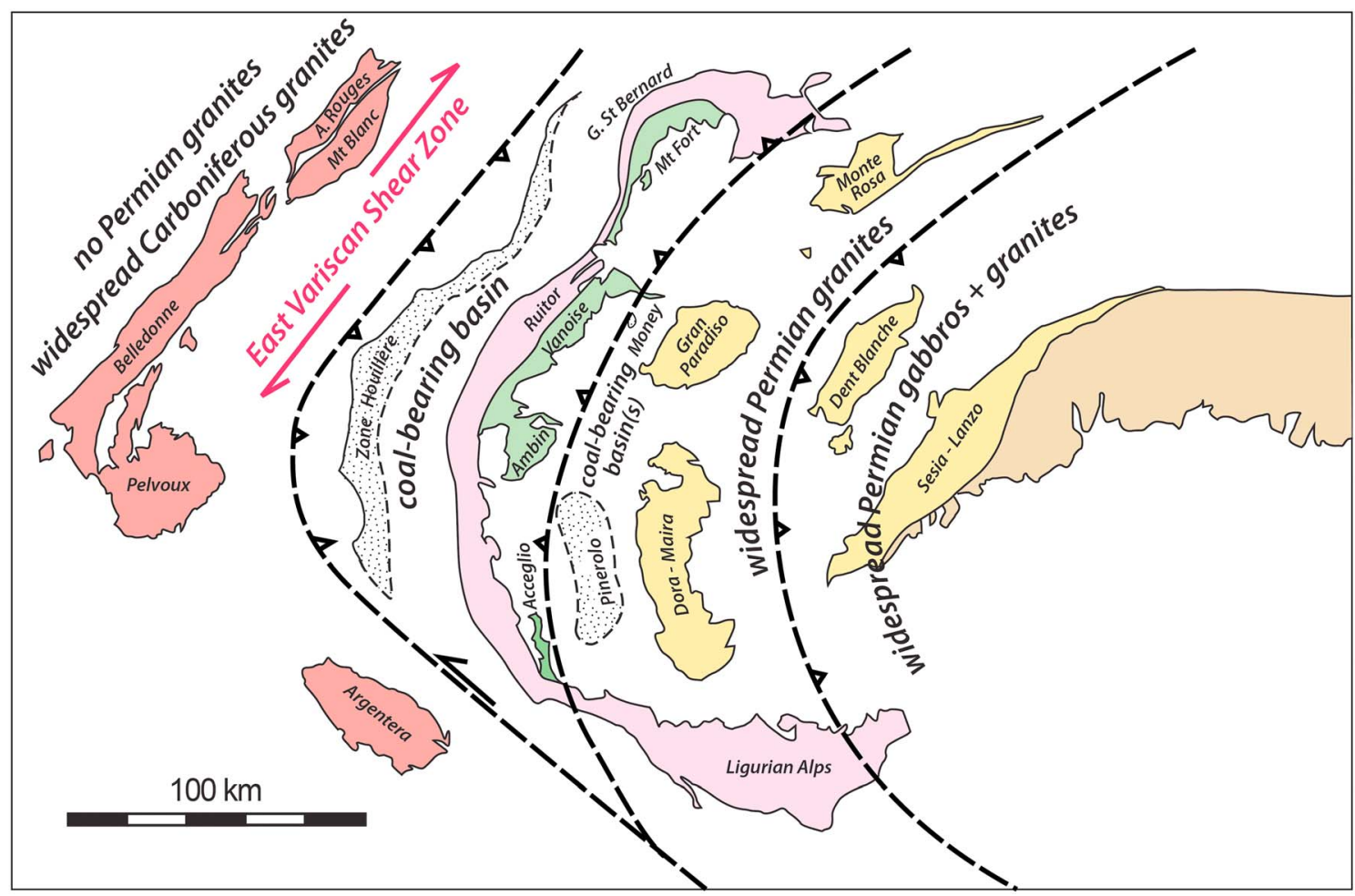

Figure 6. A summary of the main characteristics of the pre-Triassic basement in the different zones of the Western Alps. The main Alpine thrusts (in black) and the former location of the East Variscan Shear Zone (in red) are indicated. The restoration of the locations of the different units is only indicative, showing their relative position with respect to each other.

the Gzhelian basins from the Helvetic Zone share many similarities with the Gzhelian basins observed in the Variscan belt from the Massif Central to the Vosges-Schwarzwald and to Bohemia. Overall, these basins are interpreted as transtensional or extensional basins recording the collapse of the Variscan belt (Lorenz \& Nicholls, 1976; Ménard \& Molnar, 1988; Schaltegger \& Corfu, 1995) during a major kinematic flip from oblique plate convergence to plate divergence.

\subsubsection{The Zone Houillère Basin}

In contrast, the Zone Houillère basin of the Penninic Zone extends for at least 150-200 km in length and has a width of at least $20 \mathrm{~km}$. Even without taking into account its Alpine deformation, it is one of the largest Carboniferous basins. A major difference with respect to the Carboniferous basins of the Helvetic Zone is the age and duration of sedimentation, because sedimentation in the Zone Houillère has mainly taken place during the Namurian B up to the Westphalian A (Serpukhovian to Bashkirian), that is, about 10 Ma earlier than in the Helvetic Zone, possibly up to the Stephanian (Gzhelian). The internal architecture of the Carboniferous deposits, with thicker deposits earlier in the south, and later to the north, suggests a migration of the depocenters during the Late Carboniferous. However, the age of the northern (younger) deposits has to be reassessed.

The tectonic origin of the Zone Houillère basin has never been properly investigated. In any case the Zone Houillère basin is not comparable with the external flexural basins found on both sides of the Variscan belt, which are developed from the Namurian to the Westphalian and which are typically paralic, that is, recording cyclic marine incursions associated to the Carboniferous glacial fluctuations. Greber (1965) specifically mentions that although looking for marine intercalations, because the age and size of the Zone Houillère basin was akin to the foreland basin in northern France to Germany, he was unable to find any marine sediment. In accordance with Greber (1965), the Zone Houillère basin displays much more similarities with the Saar-Nahe basin, whose intramontane, limnic, deposits accumulated up to a of thickness of $6 \mathrm{~km}$. The tectonic context of the Saar-Nahe basin, much better known because there is almost no Alpine inversion, is considered as a transtensional basin opened along and reactivating a major Variscan suture zone (e.g., 


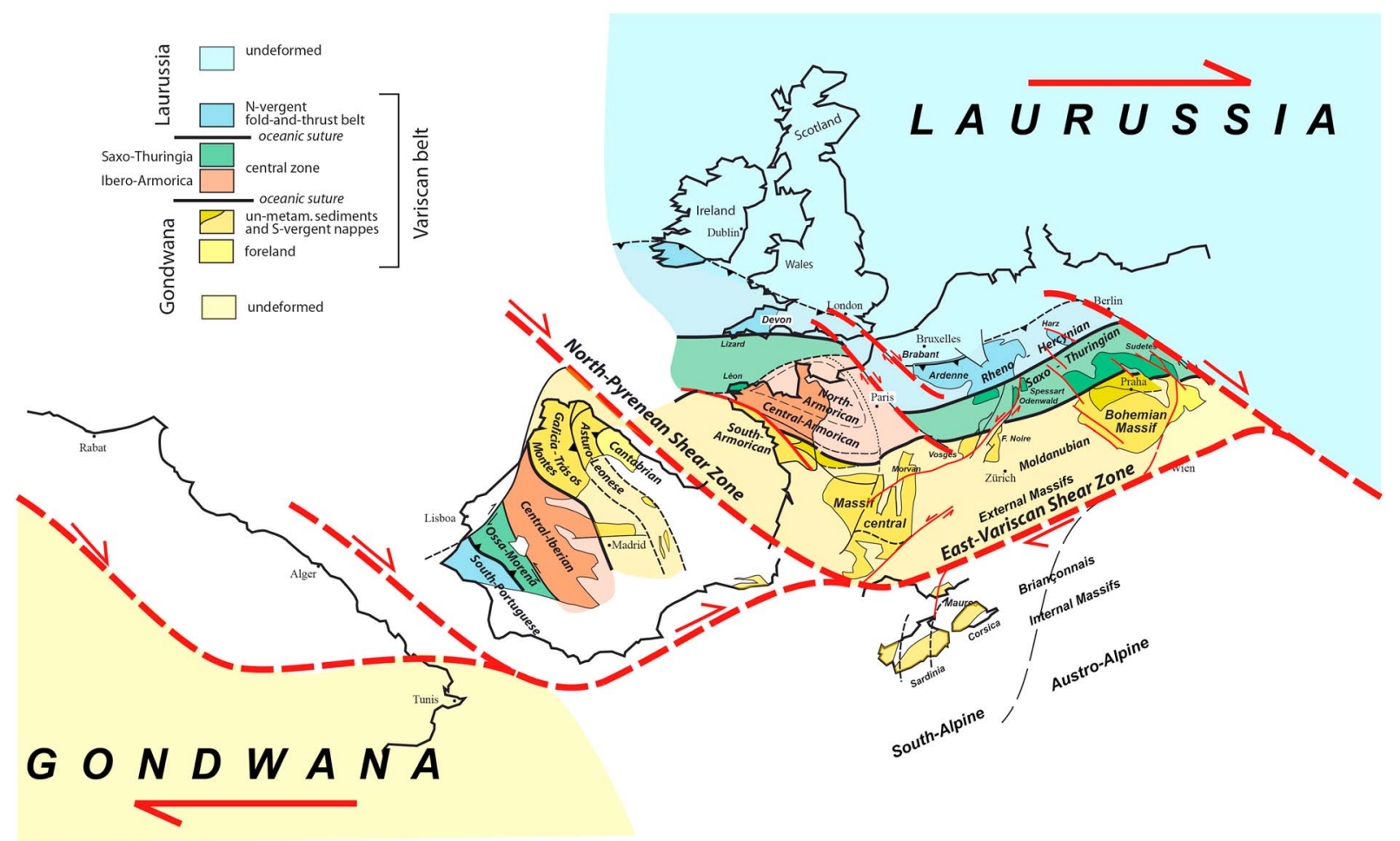

Figure 7. A paleogeographical reconstruction of southern Europe during the Permian. The structural zonation of the Variscan belt has been severely overprinted by large displacements along dextral strike-slip fault zones. One of these, namely, the East Variscan Shear Zone, may have separated the future Helvetic and Briançonnais domains. The location of the Briançonnais, South-Alpine and Austro-Alpine domains is only indicative.

Korsch \& Schäfer, 1995; Schäfer, 2011), that is, the boundary between the Avalonian domain to the north and the Armorica-Gondwana domain to the south.

In analogy, we propose to interpret the Zone Houillère as a transtensional basin opened along a major, crustal-scale, fault zone of Namurian-early Westphalian age (i.e., about 320-310 Ma). The kinematics of this Carboniferous fault are difficult to decipher. The fault itself is no more exposed and has been reactivated several times, from Jurassic rifting to Oligo-Miocene shortening. However, pending further work on its exact age based on its fossil flora, the migration of the depocenters inside the basin is consistent with dextral shearing along the bounding fault. How much displacement can be accommodated along this fault remains speculative, but an order of a few hundreds of kilometers is plausible.

With respect to the model of the EVSZ discussed earlier (Figure 7), the Zone Houillère Basin possibly was kinematically linked to the dextral displacement along this fault (or one of its predecessors). However, in contrast to proposed hypotheses (i.e., Carosi et al., 2012; Duchesne et al., 2013; Guillot et al., 2009) the EVSZ would not define the southeastern boundary of the Variscan belt, along its contact with an undeformed Gondwana basement, but would rather be located inside the Variscan belt. This is because some pre-Triassic basement complexes east of the EVSZ undisputedly record a tectonic-metamorphic event of Carboniferous age.

\subsection{Extent and Nature of the "Permian Event"}

Since its recognition in the Eastern Alps, the Permian event has been widely acknowledged in the pre-Triassic basement from the South-Alpine and Austroalpine basement (Kunz et al., 2017; Mayer et al., 2000; Petri et al., 2017; Schuster \& Stüwe, 2008; Vavra et al., 1996, 1999; Voshage et al., 1987) and the Margna and Sesia-Dent Blanche Tectonic System (e.g., Cenki-Tok et al., 2011; Dal Piaz et al., 1977; Kunz et al., 2017; Manzotti et al., 2012; Manzotti, Ballèvre, \& Dal Piaz, 2017; Manzotti, Rubatto, et al., 2017). Further west, the data summarized in this paper (Figures 4 and 5) indicate that the Permian event is widespread in the (future) Briançonnais basement but is lacking in the (future) Helvetic basement, that is, in the External Massifs. To a first order, the boundary between these two basement types represents the westernmost areal extension of the Permian 
event. This is not to say that Permian magmatism and sedimentation is absent further west. Indeed, Permian magmatism is reduced or lacking over large areas (e.g., the Armorican Massif), although sporadically present in most Permian basins. The most notable exception is provided by the very thick (up to $9 \mathrm{~km}$ ) Permian deposits from the English Channel (Ruffell et al., 2006), and the time-equivalent Cornubian granitoids (Chen et al., 1993). Further evidence for the Permian reequilibration of the lower crust is provided by the granulite-facies enclaves in the Neogene alkaline basalts throughout western and central Europe (e.g., Berger et al., 2007; Brousse \& Rudel, 1964; Féménias et al., 2003; Leyreloup, 1974). However, by comparison with the South-Alpine, Austroalpine and Briançonnais basement complexes, the amount of Permian magmatism in western and central Europe is much more moderate.

Some considerations about the geodynamic setting of the Permian event are therefore necessary for understanding its control on the future Alpine belt. The Permian amphibolite- to granulite-facies metamorphism associated to ductile, extensional, shearing in the lower crust may be interpreted either as recording the collapse of the Variscan belt following its crustal thickening during the Carboniferous or may be related to an independent process overprinting the Variscan belt. In the Variscan belt, the transition from the latest Carboniferous ("Stephanian") to the earliest Permian (Autunian: Pellenard et al., 2017) is associated with a drastic change in the tectonic setting. Propagation of thrusting and development of the associated foreland basins ceases abruptly (in less than a few million years) at about 305-300 Ma, and numerous fault-bounded basins develop all over the Variscan belt, combining transcurrent and normal faulting. This kinematic change is generally associated to a large-scale dextral displacement between Laurussia to the north and Gondwana to the south (e.g., Ziegler, 1989, plate 10; Matte, 2001; Martínez-Catalàn, 2011b). As a result, the whole of the Variscan belt has been cut across by conjuguate ductile-to-brittle fault zones (e.g., Arthaud \& Matte, 1975, 1977), while its southern margin has been severely obliterated by strike-slip faults (Figure 7). The EVSZ was most probably one of these fault zones, although its exact geometry is still speculative, as well as its geometrical-kinematical connections with the other fault zones (e.g., Schaltegger \& Brack, 2007). In the model here proposed, the EVSZ would cut across the Variscan belt. It is not, as proposed earlier, the boundary between the Carboniferous thickened crust to the north, and an undeformed Gondwana continent to the south (e.g., Carosi et al., 2012; Duchesne et al., 2013; Guillot \& Ménot, 2009).

Most, if not all, of the fault zones have been reactivated at a later stage. Specifically, the North Pyrenean Shear Zone may have controlled the oblique opening of the mid-Cretaceous mantle-floored basins in the future Pyrenean belt (Clerc et al., 2012; Lagabrielle \& Bodinier, 2008). Similarly, we propose that the location of the mantle-floored Valaisan Basin, of Cretaceous age (Beltrando et al., 2012; Loprieno et al., 2010), is inherited from the EVSZ.

\subsection{Structural Inheritance in the Alpine Belt}

\subsubsection{Structural Inheritance in the Helvetic Zone}

In the External Massifs, the boundaries between the three main domains are defined by steeply dipping mylonitic fault zones (Figure 3), whose age and kinematics is a matter of debate due to the superposition of several episodes of deformation. Some movements may have occurred already during the Late Carboniferous and the Permian, and these faults may have been reactivated during the Triassic-Jurassic rifting as well as during the Oligo-Miocene transpressive crustal shortening. A classic example is the "synclinal median" (median syncline) that divides the Belledonne massif in two parts, leaving domain I to the west and domains II and III to the east. The synclinal median is marked by the occurrence of a narrow strip of Mesozoic sediments, observed both in outcrop and in the hydroelectric power plants in the Arc and Isère valleys (Bordet, 1961; Gasquet et al., 1981). These sediments mark the trace of a major thrust, the internal Belledonne (i.e., domain III) being thrust over the external Belledonne (i.e., domain I) along a steep east dipping plane. However, the differences in lithology on both sides of the synclinal median cannot be explained only by a Miocene thrusting but reveal that the Alpine thrust reworks a polyphased pre-Alpine fault, that is, a Jurassic normal fault (Barféty et al., 1979; Lemoine et al., 1981), itself reactivating a Late Paleozoic transcurrent fault (Arthaud \& Matte, 1977).

Structural inheritance therefore plays a major role in the Helvetic Zone, contributing to localize the future (Liassic) normal faults, which may or may not ultimately evolve into reverse faults during the Alpine shortening (Bellahsen et al., 2012, 2014; Gillcrist et al., 1987). Preservation of the Liassic normal faults along the South Belledonne-Pelvoux transect results from a combination of (i) the arcuate pattern of the External Massifs 


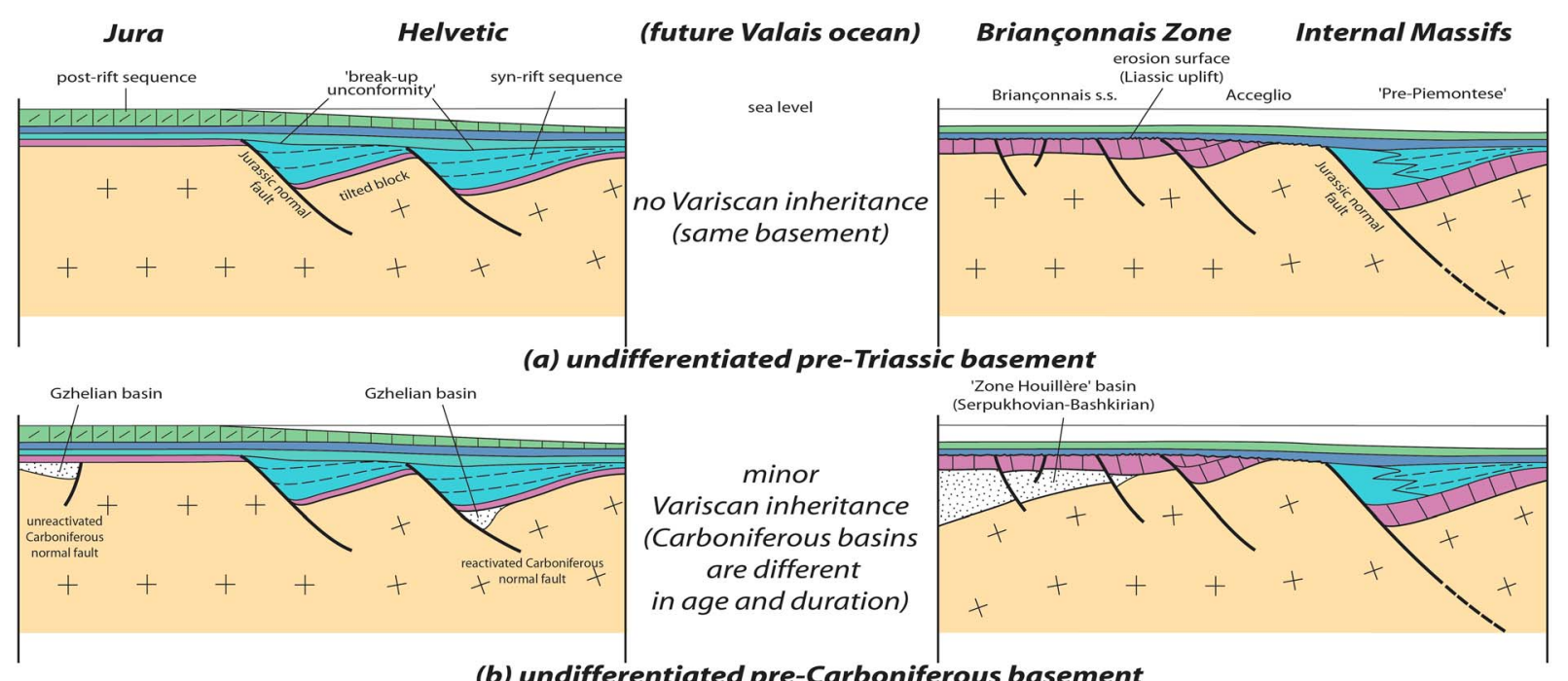

(b) undifferentiated pre-Carboniferous basement
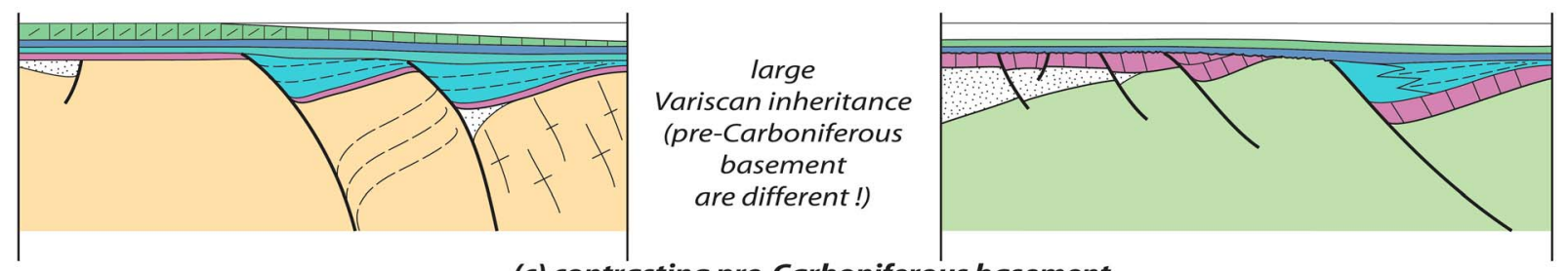

(c) contrasting pre-Carboniferous basement

Figure 8. A summary of our knowledge of the pre-Triassic basement in the Helvetic and Penninic Zones and its consequences for the Variscan inheritance in the future Alpine belt. The angular relationships between the basement structures and the Triassic cover is unknown below the Jura Mountains (because it is only accessible by boreholes) but is well preserved in the Helvetic Zone. By contrast, it is no more accessible in the Penninic Zone due to intense Alpine reworking.

inherited from the pre-Alpine history and (ii) the increasing amount of Alpine crustal shortening from south to north (e.g., Bellahsen et al., 2014).

\subsubsection{Structural Inheritance Along the Future Helvetic/Penninic Boundary}

For the sake of clarity, we proceed in three steps (Figure 8). First, we recall that the Helvetic and (Middle) Penninic Zones have contrasting Mesozoic sedimentary sequences, reflecting differences in the history of rifting and subsidence during the Jurassic (Figure 8). Specifically, the most notable difference is the occurrence of thick sequences of synrift Liassic deposits in the Helvetic Zone, as opposed to their absence in the Briançonnais domain, which was uplifted and eroded during the same period (e.g., Baud \& Masson, 1975; Claudel \& Dumont, 1999; Decarlis \& Lualdi, 2008). While emphasizing these differences, most authors leave the pre-Triassic basement undifferentiated (Figure 8a), either for the sake of convenience (because there is no need to discuss the pre-Triassic basement in order to understand the Jurassic rifting) or because they implicitly consider that the basements had the same history in both zones. With such premises, the question of inheritance is therefore not addressed in their study.

However, we propose that one has to take into account the differences in the Carboniferous and Permian history recorded by the pre-Triassic basement complexes of the Helvetic and Penninic Zones (Figure 8b). These having been detailed above may be summarized as follows. First, Permian magmatism is almost absent in the Helvetic Zone, whereas it is widespread in the Penninic Zone (from the dykes and sills of the Zone Houillère to the huge granitoid intrusions of the Internal Massifs). Second, the Carboniferous sedimentation in the two Zones also reveals contrasting patterns: the small, short-lived basins in the Helvetic Zone developed later (mostly during the Gzhelian) than the large, long-lived basin of the Zone Houillère (mostly SerpukhovianBashkirian, with probable renewed sedimentation during the Gzhelian). The best explanation for the tectonic development of the latter basin is transtensive movement along a crustal-scale fault accommodating a large amount of displacement inside the Variscan belt. As a consequence, we need to consider that the pre-Upper 

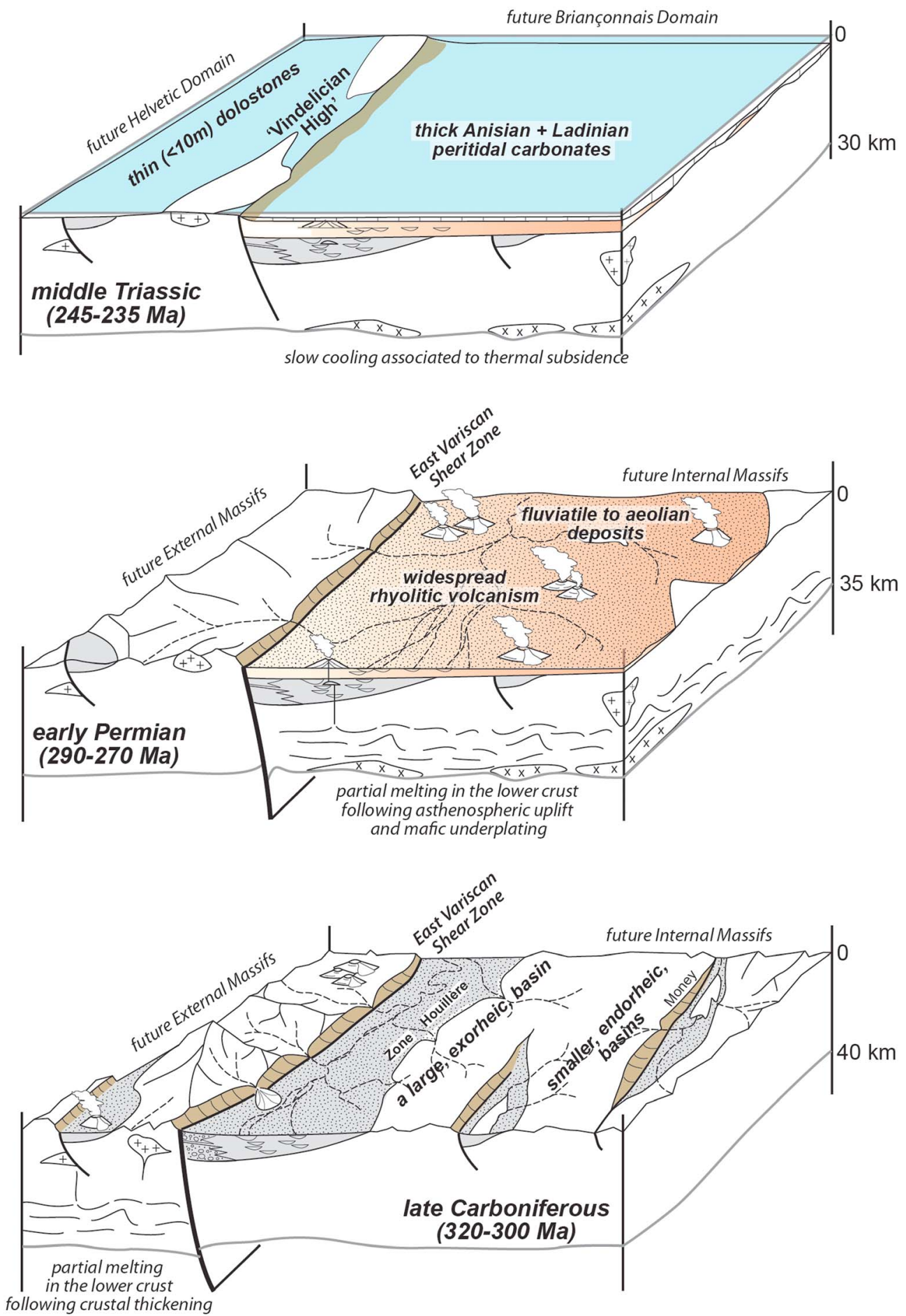

Figure 9. Three steps in the tectonosedimentary history of the future Helvetic/Penninic boundary region. The schematic, crustal-scale drawings emphasize the link between the large-scale displacement along the East Variscan Shear Zone, the thermal state of the crust, and the sedimentation patterns during the Late Carboniferous (a), the Early Permian (b), and the Middle Triassic (c). 
Carboniferous basements of the Helvetic and (Middle) Penninic Zones may have different Variscan (and possibly also pre-Variscan) histories on both sides of the future Penninic Front.

The final step in this discussion is to integrate the history of the Variscan basement itself (Figure 8c). All authors agree that the pre-Triassic basement in the Helvetic Zone has the same history as that of the Massif Central, Vosges-Schwarzwald, and Moldanubian from the Bohemian Massif, with the salient features being the occurrence of Cambro-Ordovician ophiolite relics, the early eclogite-facies event, followed by high-grade metamorphism associated with extensive partial melting and, finally, large amounts of Carboniferous granitoids (their age covering an interval ending close to the Carboniferous/Permian boundary, at about 300-295 Ma). By contrast, the pre-Triassic basement in the Penninic zone is rather diverse, with some Early Paleozoic rocks devoid of a significant (i.e., higher than greenschist facies) Variscan overprint. Carboniferous granitoids are very rare in the Penninic Zone, whereas the Permian magmatism is largely developed. In this sense, the basement of the Penninic Zone has much more in common with the SouthAlpine basement (Dal Piaz, 1993; Dal Piaz \& Martin, 1998) than with the Helvetic basement, characterized by a high thermal regime accompanying crustal (lithospheric) extension of Permian age (e.g., Schuster \& Stüwe, 2008; Schuster et al., 2001).

The distinct sedimentary evolutions during the Triassic may be related to this Permian event (Figure 9). To the east, where the Permian event is largely developed, the thermal subsidence during the Triassic allowed for the deposition of a thick carbonate platform. On the contrary, to the west (i.e., in the Helvetic Zone and further west), thermal subsidence did not take place during the Triassic, and therefore, accommodation space was negligible, as recorded by the sediments not exceeding a few meters in thickness. The two sedimentary domains were separated by the "Vindelician High," a low-elevation area preventing an easy communication between the "Germanic Trias" to the north and the "Alpine Trias" to the south (Hauschke \& Wilde, 1999; Ziegler, 1993; von Gümbel, 1891).

In summary, we propose that the Helvetic basement was separated during Carboniferous times from the Penninic basement by a huge transcurrent shear zone, that is, the EVSZ. This hypothesis is in accordance with most recent models that have discussed the tectonic evolution of the pre-Triassic basement in the Helvetic Zone (e.g., Corsini \& Rolland, 2009; Guillot \& Ménot, 2009; Guillot et al., 2009; Hernandez et al., 2002; Matte, 2001). In complement to these models, we emphasize that the Zone Houillère records the birth and growth of a large, long-lived intramontane sedimentary basin, which is contemporaneous with the transcurrent displacement. This model is also similar to the one proposed by Bussy et al. (2000) and von Raumer et al. (2009), although their location of the different Alpine basement complexes is sometimes difficult to master. This zone of weakness has been reactivated many times during the Mesozoic, recorded by the diversity of the sedimentary sequences of the so-called Subbriançonnais Units, and allowing at least in its northern part the exposure of the mantle floor (Valaisan Basin). The final consequence of this long-lasting reactivation is that the pre-Carboniferous basements on both sides of the Penninic Thrust had contrasting geological histories during the Variscan orogeny.

\section{Conclusions}

This study provides the following main conclusions.

1. Carboniferous deposits in the Helvetic Zone are mostly Ghzelian in age (305-300 Ma) and took place in narrow basins, controlled by extensional tectonics related to late collapse of the Variscan belt. The source of the detrital material was local.

2. The source of the detrital material that was deposited during the Namurian to Westphalian A in the Zone Houillère was the Early Carboniferous granitic magmatism in the Helvetic Zone. The same source provided detrital material to the Pinerolo sediments but not to the Money window.

3. The Zone Houillère basin was located along a major, crustal-scale transcurrent shear zone (the EVSZ) that accommodated a large displacement of the structural domains within the Variscan belt, cutting across its large-scale zonation. This movement has taken place at 320-310 Ma and is contemporaneous with the late, transcurrent deformation observed in the Helvetic Zone, and allowing for the intrusion of the granitic magmatism.

4. This zone of crustal weakness was reactivated several times. During the Permian, it marks the westernmost boundary of the extensive partial melting in the lower crust, whatever its ultimate cause may be. 
From the Triassic onward, it controlled the sedimentation on top of the continental crust (Helvetic versus Briançonnais type). During the Jurassic and the Cretaceous, it allowed the opening of the Valaisan Basin.

\section{Acknowledgments}

This work has been funded through a research grant from the Université de Rennes 1 (Défis Scientifiques Emergents). The help of Catherine Schlegel Rey (librarian at the Institute of Earth Sciences in Lausanne) was precious for finding key old documents. This paper results from many discussions with colleagues in several institutions, too numerous to be cited here. However, the authors are solely responsible for the conclusions expressed in this work. Perceptive and critical reviews provided by J. M. Pownall and S. M. Schmid are acknowledged. Further discussions with $\mathrm{H}$. Masson, J. R. Martínez Catalán, S. M. Schmid, A. Steck, and R. Schuster have helped clarifying some of the largescale issues.

\section{References}

Abrecht, J., \& Biino, G. (1994). The metagabbros of the Kastelhorn area (Gotthard massif, Switzerland): Their metamorphic history inferred from mineralogy and texture. Schweizerische Mineralogische und Petrographische Mitteilungen, 74, 53-68.

Abrecht, J., Biino, G., Mercolli, I., \& Stille, P. (1991). Mafic-ultramafic rock associations in the Aar, Gotthard and Tavetsch massifs of the Helvetic domain in the Central Swiss Alps: Markers of ophiolitic pre-Variscan sutures, reworked by polymetamorphic events? Schweizerische Mineralogische und Petrographische Mitteilungen, 71, 295-300.

Antoine, P. (1971). La zone des brèches de Tarentaise entre Bourg Saint-Maurice (vallée de l'Isère) et la frontière italo-suisse, Mémoires du Laboratoire de Géologie de I'Université de Grenoble, 9, p. 367.

Argand, E. (1911). Les nappes de recouvrement des Alpes Pennines et leurs prolongements structuraux. Matériaux pour la Carte Géologique de la Suisse, Nouvelle Série, 31, p. 26.

Arthaud, F., \& Matte, P. (1975). Les décrochements tardi-hercyniens du sud-ouest de l'Europe. Géométrie et essai de reconstitution des conditions de la déformation. Tectonophysics, 25, 139-171.

Arthaud, F., \& Matte, P. (1977). Late Paleozoic strike-slip faulting in southern Europe and northern Africa. Geological Society of America Bulletin, $88,1305-1320$

Badertscher, N., \& Burkhard, M. (1998). Inversion alpine du graben Permo-Carbonifère de Salvan-Dorénaz et sa relation avec le chevauchement de la nappe de Morcles sus-jacente. Eclogae Geologicae Helvetiae, 91, 359-373.

Bakos, F., Del Moro, A., \& Visonà, D. (1990). The Hercynian volcano-plutonic association of Ganna (Lake Lugano, central Southern Alps, Italy). European Journal of Mineralogy, 2, 373-383.

Ballèvre, M., Martínez-Catalàn, J. R., López-Carmona, A., Pitra, P., Abati, J., Díez Fernández, R., et al. (2014). Correlation of the nappe stack in the Ibero-Armorican arc across the Bay of Biscay: A joint French-Spanish project. In K. Schulmann, et al. (Eds.), The Variscan orogeny: Extent, timescale and the formation of the European crust, Geological Society, London, Special Publications (Vol. 405, pp. 77-113).

Banzet, G., Lapierre, H., Le Fort, P., \& Pêcher, A. (1985). Le volcanisme Carbonifère-supérieur du massif des Grandes Rousses (Zone dauphinoise-Alpes externes françaises): Un magmatisme à affinités shoshonitiques lié à la fracturation crustale tardi-varisque. Géologie Alpine, 61, 33-60.

Banzet, G., Rouer, O., \& Lapierre, H. (1984). Nouvelles données pétrographiques, stratigraphiques et structurales sur le volcanisme carbonifère du col de la Croix-de-Fer (Alpes externes). Bulletin de la Société Géologique de France, 16(6), 1269-1280.

Barbier, R., \& Trümpy, R. (1955). Sur l'âge du flysch de la zone des brèches de Tarentaise. Bulletin de la Société Géologique de France, 5(6), 207-216.

Bard, J.-P., Capdevila, R., \& Matte, P. (1971). Structure de la chaîne hercynienne de la Meseta ibérique: Comparaison avec les segments voisins In Histoire Structurale du Golfe de Gascogne (Vol. 4, pp. 1-68). Paris: Pub. Inst. Fr. Pétrole.

Barféty, J.-C., Blaise, J., Fourneaux, J.-C., \& Méloux, J. (1984). Notice explicative de la feuille La Rochette à 1/50 000, BRGM, Orléans, p. 45.

Barféty, J.-C., Gidon, M., Lemoine, M., \& Mouterde, R. (1979). Tectonique synsédimentaire liasique dans les massifs cristallins de la zone externe des Alpes occidentales françaises: la faille du col d'Ornon. Comptes Rendus de l'Académie des Sciences Paris, II, 289, 1207-1210.

Basso, A.-M. (1987). Les formations carbonifères de la Provence orientale (sud-Est de la France). Géologie Alpine, Mémoire, Hors-Série, 13, 19-24.

Baud, A., \& Masson, H. (1975). Preuves d'une tectonique liasique de distension dans le domaine briançonnais: Failles conjuguées et paléokarts à Saint-Triphon (Préalpes Médiames, suisse). Eclogae Geologicae Helvetiae, 68, 131-145.

Bearth, P. (1952). Geologie und Petrographie des Monte Rosa. Beiträge zur Geologischen Karte der Schweiz, Neue Folge, 96, p. 94.

Bellahsen, N., Jolivet, L., Lacombe, O., Bellanger, M., Boutoux, A., Garcia, S., et al. (2012). Mechanisms of margin inversion in the external Western Alps: Implications for crustal rheology. Tectonophysics, 560-561, 62-83.

Bellahsen, N., Mouthereau, F., Boutoux, A., Bellanger, M., Lacombe, O., Jolivet, L., \& Rolland, Y. (2014). Collision kinematics in the western external Alps. Tectonics, 33, 1055-1088. https://doi.org/10.1002/2013TC003453

Bellet, J. (1933). Note sur la flore stéphanienne du Houiller des Grandes Rousses. Association Française pour l'Avancement des Sciences, 57, 229-231.

Beltrando, M., Compagnoni, R., \& Lombardo, B. (2010). (Ultra-) High-pressure metamorphism and orogenesis: An Alpine perspective. Gondwana Research, 18, 147-166.

Beltrando, M., Frasca, G., Compagnoni, R., \& Vitale Brovarone, A. (2012). The Valaisan controversy revisited: Multi-stage folding of a Mesozoic hyper-extended margin in the Petit St. Bernard area (Western Alps). Tectonophysics, 579, 17-36.

Beltrando, M., Rubatto, D., Compagnoni, R., \& Lister, G. (2007). Was the Valaisan basin floored by oceanic crust? Evidence of Permian magmatism in the Versoyen Unit (Valaisan domain, NW Alps). Ofioliti, 32, 85-99.

Beltrando, M., Rubatto, D., \& Manatschal, G. (2010). From passive margins to orogens: The link between ocean-continent transition zones and (ultra)high-pressure metamorphism. Geology, 38, 559-562.

Berger, J., Féménias, O., Coussaert, N., Mercier, J.-C. C., \& Demaiffe, D. (2007). Cumulating processes at the crust-mantle transition zone inferred from Permian mafic-ultramafic xenoliths (Puy Beaunit, France). Contributions to Mineralogy and Petrology, 153, $557-575$.

Berger, A., Mercolli, l., Herwegh, M., \& Gnos, E. (2017). Geological map of the Aar Masif, Tavetsch and Gotthard Nappes. Geol. Spec. Map 1:100 000, explanatory notes 129. Federal Office of Topography Swisstopo.

Bergomi, M. A., Dal Piaz, G. V., Malusà, M. G., Monopoli, B., \& Tunesi, A. (2017). The Grand St Bernard-Briançonnais nappe system and the Paleozoic puzzle of the Western Alps unraveled by zircon U-Pb dating. Tectonics, 36, 2950-2972. https://doi.org/10.1002/2017TC004621

Bertrand, P. (1926). Les gisements à Mixoneura de la région de Saint-Gervais-Chamonix. Bulletin de la Société Géologique de France, 26(4), 381-388.

Bertrand, J.-M. (1968). Etude structurale du versant occidental du Massif du Grand Paradis (Alpes Graies). Géologie Alpine, $44,55-87$.

Bertrand, J.-M., Guillot, F., Leterrier, J., Perruchot, M.-P., Aillères, L., \& Macaudière, J. (1998). Granitoïdes de la zone houillère briançonnaise en Savoie et en Val d'Aoste (Alpes occidentales): Géologie et géochronologie U-Pb sur zircon. Geodinamica Acta, $11,33-49$.

Bertrand, J.-M., \& Leterrier, J. (1997). Granitoïdes d'âge Paléozoïque inférieur dans le socle de Vanoise méridionale: Géochronologie U-Pb du métagranite de I'Arpont (Alpes de Savoie, France). Comptes Rendus de l'Académie des Sciences Paris, II, 325, 839-844.

Bertrand, J.-M., Paquette, J.-L., \& Guillot, F. (2005). Permian zircon U-Pb ages in the Gran Paradiso massif: Revisiting post-Variscan events in the Western Alps. Schweizerische Mineralogische und Petrographische Mitteilungen, 85, 15-29. 
Bertrand, J.-M., Pidgeon, R. T., Leterrier, J., Guillot, F., Gasquet, D., \& Gattiglio, M. (2000). SHRIMP and IDTIMS U-Pb zircon ages of the pre-Alpine basement in the Internal Western Alps (Savoy and Piemont). Schweizerische Mineralogische und Petrographische Mitteilungen, 80, 225-248.

Beucler, M., Guillot, F., \& Hernandez, J. (2000). Les granophyres du Mont-Pourri (Vanoise septentrionale-Savoie): Lithostratigraphie et pétrologie. Bulletin de la Société Vaudoise des Sciences Naturelles, 87, 29-60.

Biino, G. (1994). The pre Late Ordovician metamorphic evolution of the Gotthard-Tavetsch massifs (Central Alps): From lawsonite to kyanite eclogites to granulite retrogression. Schweizerische Mineralogische und Petrographische Mitteilungen, 74, 87-104.

Biino, G. (1997). Pre-Variscan evolution of the eclogitised mafic rocks from the Helvetic basement of the central Alps. European Journal of Mineralogy, 7, 57-70.

Bloch, J.-P. (1966). Le Permien du domaine briançonnais ligure. Essai de chronologie des formations antétriasiques, Atti del Symposium sul Verrucano (Pisa, Settembre 1965), Società Toscana di Scienze Naturali, 99-115.

Bocquet, J. (1974). II metamorfismo prealpino nella Vanoise (Savoia) e in altri settori dello zoccolo brianzonese. Memorie della Società Geologica Italiana, 13, 271-284.

Bodinier, J.-L., Dupuy, C., Dostal, J., \& Carme, F. (1981). Geochemistry of ophiolites from the Chamrousse complex (Belledonne massif, Alps). Contributions to Mineralogy and Petrology, 78, 379-388.

Bordet, P. (1951). Etude géologique et pétrographique de l'Estérel, Mém. Serv. Carte Géol. France, Paris (Imprimerie Nationale), p. 207.

Bordet, C. (1961). Recherches géologiques sur la partie septentrionale du massif de Belledonne (Alpes françaises). Mém. Serv. Carte Géol. France, Paris, $218 \mathrm{pp}$.

Bordet, P., \& Bordet, C. (1963). Belledonne-Grandes Rousses et Aiguilles Rouges-Mont Blanc: Quelques données nouvelles sur leurs rapports structuraux. Livre à la mémoire du Professeur Paul Fallot, Société Géologique de France, II, 309-316.

Bordet, P., \& Corsin, P. (1951). Flore stéphanienne dans le massif des Grandes Rousses, C.R. sommaire séances Soc. Géol. France (5 mars 1951 ) 73-74.

Borghi, A., Cadoppi, P., Porro, A., \& Sacchi, R. (1985). Metamorphism in the north part of the Dora-Maira Massif (Cottian Alps). Bolletino del Museo Regionale di Scienze Naturali (Torino), 3, 369-380.

Borghi, A., Gattiglio, M., Mondino, F., \& Zaccone, G. (1999). Structural and metamorphic evidence of pre-Alpine basement in the Ambin nappe (Cottian Alps, Italy). Memorie di Scienze Geologiche di Padova, 51, 205-220.

Borghi, A., \& Sandrone, R. (1995). Petrological constraints on the Alpine P-T history of the internal Pennine nappes of the Western Alps. Bolletino del Museo Regionale di Scienze Naturali (Torino), 13, 241-272.

Boriani, A., Dal Piaz, G. V., Hunziker, J. C., von Raumer, J., \& Sassi, F. P. (1974). Caratteri, distribuzione ed età del metamorfismo prealpino nelle Alpi. Memorie della Società Geologica Italiana, 13, 165-225.

Bouffette, J., Lardeaux, J.-M., \& Caron, J.-M. (1993). Le passage des granulites aux éclogites dans les métapélites de l'unité de la Punta Muret (Massif Dora-Maira, Alpes occidentales). Comptes Rendus de Academie des Sciences Paris Serie II, 317, 1617-1624.

Bouroz, A., \& Corsin, P. (1950). Sur l'âge du Houiller du Bassin de la Mure et de la zone externe des Alpes. Comptes Rendus de Academie des Sciences Paris, 220, 2035-2037.

Bousquet, R., Oberhänsli, R., Schmid, S. M., Berger, A., Wiederkehr, M., C. Robert, et al. (2012). Metamorphic framework of the Alps. Commission for the Geological Map of the World.

Boutoux, A., Bellahsen, N., Nanni, U., Pik, R., Verlaguet, A., Rolland, Y., \& Lacombe, O. (2016). Thermal and structural evolution of the external Western Alps: Insights from (U-Th-Sm)/He thermochronology and RSCM thermometry in the Aiguilles Rouges/Mont Blanc massifs. Tectonophysics, 683, 109-123.

Brousmiche Delcambre, C., Coquel, R., \& Decrouez, D. (1999). Sur la flore de deux gisements carbonifères de la Zone delphino-helvétique: Carrière d'Héry-sur-Ugine (Vallée de l'Arly); Ardoisières des Posettes (Massif des Aiguilles Rouges) - Haute-Savoie (France). Revue de Paléobiologie, 18, 317-331.

Brousmiche Delcambre, C., Coquel, R., \& Mercier, D. (1997). Sur l'âge des terrains carbonifères affleurant au col de Tramouillon (Massif de Gaulent, Sud Briançonnais). Revue de Paléobiologie, 16, 169-179.

Brousmiche Delcambre, C., Mercier, D., \& Coquel, R. (1995). Implications stratigraphiques de la révision de la flore carbonifère au Sud de Briançon. Comptes Rendus de I'Académie des Sciences Paris - Series IIA - Earth and Planetary Science, 320, 335-340.

Brousmiche Delcambre, C., Mercier, D., \& Coquel, R. (1996). Révision de la flore carbonifère du Briançonnais. Implications stratigraphiques. $1^{\text {ère }}$ partie: Vallée de la Durance au sud de Briançon. Palaeontographica B, 239(4-6), 77-107.

Brousmiche Delcambre, C., Mercier, D., \& Coquel, R. (1997). Révision de la flore carbonifère du Briançonnais. Implications stratigraphiques. Partie II: Le Nord de Briançon, de la vallée de la Guisane à celle de la Clarée. Palaeontographica B, 248(4-6), 87-125.

Brousmiche-Delcambre, C., \& Menkveld-Gfeller, U. (2007). La macroflore carbonifère du tunnel de base du Lötschberg (Oberland bernois, Suisse). Revue de Paléobiologie, 26, 645-663.

Brousse, R., \& Rudel, A. (1964). Bombes de péridotites, de norites, de charnockites et de granulites dans les scories du Puy Beaunit. Comptes rendus de l'Académie des Sciences Paris, Série D - Sciences Naturelles, 259, 185-188.

Burri, M. (1983a). Description géologique du front du Saint-Bernard dans les vallées de Bagnes et d'Entremont (Valais). Bulletin de Géologie Lausanne, 270, 1-88.

Burri, M. (1983b). Le front du Grand St-Bernard du val d'Hérens au val d'Aoste. Eclogae Geologicae Helvetiae, 76, 469-490.

Bussien Grosjean, D., Meisser, N., May-Leresche, S., Ulianov, A., \& Vonlanthen, P. (2017). The Morcles microgranite (Aiguilles Rouges, Swiss Alps): Geochronological and geochemical evidences for a common origin with the Vallorcine intrusion. Swiss Journal of Geosciences, 110. https://doi.org/10.1007/s00015-017-0282-3

Bussy, F., \& Cadoppi, P. (1996). U-Pb zircon dating of granitoids from the Dora-Maira massif (western Italian Alps). Schweizerische Mineralogische und Petrographische Mitteilungen, 76, 217-233.

Bussy, F., Delitroz, D., Fellay, R., \& Hernandez, J. (1998). The Pormenaz Monzonite (Aiguilles Rouges, western Alps): An additional evidence for a 330 Ma-old magnesio-potassic magmatic suite in the Variscan. Schweizerische Mineralogische und Petrographische Mitteilungen, 78, 193-194.

Bussy, F., Derron, M.-H., Jacquod, J., Sartori, M., \& Thélin, P. (1996). The 500 Ma-old Thyon metagranite: A new A-type occurrence in the western Penninic Alps (Wallis, Switzerland). European Journal of Mineralogy, 8, 565-575.

Bussy, F., \& Hernandez, J. (1997). Short-lived bimodal magmatism at 307my in the Mont Blanc/Aiguilles Rouges area: A combination of decompression melting, basaltic underplating and crustal fracturing. Third Workshop on Alpine Geological Studies (Biella, 1997), Quaderni di Geodinamica Alpina e Quaternaria, 4, 22.

Bussy, F., Hernandez, J., \& von Raumer, J. F. (2000). Bimodal magmatism as a consequence of the post-collisional readjustment of the thickened Variscan continental lithosphere (Aiguilles Rouges-Mont Blanc Massifs, Western Alps). Transactions of the Royal Society of Edinburgh: Earth Sciences, 91, 221-233. 
Bussy, F., Péronnet, V., Ulianov, A., Epard, J.-L., \& von Raumer, J. (2011). Ordovician magmatism in the external French Alps: Witness of a peri-Gondwanan active continental margin. In Ordovician of the world, Cuaderno Museo Geominero (Vol. 14, pp. 75-82). Madrid: Instituto Geoloógico y Minero de Espanña.

Bussy, F., Sartori, M., \& Thélin, P. (1996). U-Pb dating in the middle Penninic basement of the Western Alps (Valais, Switzerland). Schweizerische Mineralogische und Petrographische Mitteilungen, 76, 81-84.

Bussy, F., Venturini, G., Hunziker, J. C., \& Martinotti, G. (1998). U-Pb ages of magmatic rocks of the western Austroalpine Dent-Blanche-Sesia Unit. Schweizerische Mineralogische und Petrographische Mitteilungen, 78, 163-168.

Bussy, F., \& von Raumer, J. F. (1994). U-Pb geochronology of Paleozoic magmatic events in the Mont-Blanc Crystalline Massif, Western Alps. Schweizerische Mineralogische und Petrographische Mitteilungen, 74, 514-515.

Bussy, F., von Raumer, J., \& Capuzzo, N. (2001). Mont Blanc-Aiguilles rouges Massifs (External Massifs)—An example of polyorogenic evolution. Mémoires de Géologie Lausanne, 36, 53-84.

Butler, R. W. H. (1983). Balanced cross-sections and their implications for the deep structure of the northwest Alps. Journal of Structural Geology, 5, 127-137.

Butler, R. W. H., Tavarnelli, E., \& Grasso, M. (2006). Structural inheritance in moutain belts: An Alpine-Apennine perspective. Journal of Structural Geology, 28, 1893-1908.

Caby, R. (1968). Contribution à l'étude structurale des Alpes occidentales: Subdivisions stratigraphiques et structure de la zone du Grand Saint-Bernard dans la partie Sud du Val d'Aoste (Italie). Géologie Alpine, 44, 95-111.

Caby, R. (1974). Gneiss permo-carbonifères d'origine granitique et volcanique dans la Zone houillère et la Zone du Grand Saint-Bernard en val d'Aoste (Italie). Géologie Alpine, 50, 39-44.

Cadoppi, P. (1990). Geologia del basamento cristallino nel settore settentrionale del Massicio Dora-Maira (Alpi occidentali). Tesi di Dottorato Università di Torino, p. 208.

Callegari, E., Compagnoni, R., \& Dal Piaz, G. V. (1969). Relitti di strutture intrusive erciniche e scisti a sillimaniti nel Massicio del Gran Paradiso. Bollettino della Società Geologica Italiana, 88, 59-69.

Cannic, S., Lapierre, H., Monié, P., Briqueu, L., \& Basile, C. (2002). Late orogenic evolution of the Variscan lithosphere: Nd isotopic constraints from the Western Alps. Schweizerische Mineralogische und Petrographische Mitteilungen, 82, 77-99.

Capuzzo, N., \& Bussy, F. (2000). High-precision dating and origin of synsedimentary volcanism in the Late Carboniferous Salvan-Dorénaz basin (Aiguilles-Rouges Massif, Western Alps). Schweizerische Mineralogische und Petrographische Mitteilungen, 80, $147-167$.

Capuzzo, N., Handler, R., Neubauer, F., \& Wetzel, A. (2003). Post-collisional rapid exhumation and erosion during continental sedimentation: The example of the late Variscan Salvan-Dorénaz basin (Western Alps). International Journal of Earth Sciences, 92, 364-379.

Capuzzo, N., \& Wetzel, A. (2004). Facies and basin architecture of the Late Carboniferous Salvan-Dorénaz continental basin (Western Alps, Switzerland/France). Sedimentology, 51, 675-697.

Carosi, R., Montomoli, C., Tiepolo, M., \& Frassi, C. (2012). Geochronological constraints on post-collisional shear zones in the Variscides of Sardinia (Italy). Terra Nova, 24, 42-51.

Cenki-Tok, B., Darling, J. R., Rolland, Y., Dhuime, B., \& Storey, C. D. (2014). Direct dating of mid-crustal shear zones with syn-kinematic allanite: New in situ U-Th-Pb geochronological approaches applied to the Mont Blanc massif. Terra Nova, 26, 29-37.

Cenki-Tok, B., Oliot, E., Rubatto, D., Berger, A., Engi, M., Janots, E., et al. (2011). Preservation of Permian allanite within an Alpine eclogite facies shear zone at Mt Mucrone, Italy: Mechanicla and chemical behavior of allanite during mylonitization. Lithos, 125, 40-50.

Ceriani, S., Fügenschuh, B., \& Schmid, S. M. (2001). Multi-stage thrusting at the "Penninic Front" in the Western Alps between Mont Blanc and Pelvoux massifs. International Journal of Earth Sciences, 90, 685-702.

Ceriani, S., \& Schmid, S. M. (2004). From N-S collision to WNW-directed post-collisional thrusting and folding: Structural study of the Frontal Penninic Units in Savoie (Western Alps, France). Eclogae Geologicae Helvetiae, 97, 347-369.

Chen, Y., Clark, A., Farrar, E., Wasteneys, H. A. H. P., Hodgson, M. J., \& Bromley, A. V. (1993). Diachronous and independent histories of plutonism and mineralization in the Cornubian Batholith, southwest England. Journal of the Geological Society of London, 150, $1183-1191$.

Choukroune, P., \& Gapais, D. (1983). Strain pattern in the Aar granite (central Alps): Orthogneiss developed by bulk inhomogeneous flattenning. Journal of Structural Geology, 5, 411-418.

Claudel, M.-E., \& Dumont, T. (1999). A record of multistage continental break-up on the Briançonnais marginal plateau (Western Alps): Early and Middle-Late Jurassic rifting. Eclogae Geologicae Helvetiae, 92, 45-61.

Clerc, C., Lagabrielle, Y., Neumaier, M., Reynaud, J.-Y., \& de Saint Blanquat, M. (2012). Exhumation of subcontinental mantle rocks: Evidence from ultramafic clastic deposits nearby the Lherz peridotite body, French Pyrenees. Bulletin de la Société Géologique de France, 183, 443-459.

Colombo, F., Compagnoni, R., \& Lombardo, B. (1994). Le rocce eclogitiche dei Laghi del Frisson (Argentera sud-orientale, Alpi Marittime). Atti Ticinensi di Scienze della Terra (Pavia), Serie Speciale, 1, 75-82.

Compagnoni, R., Elter, G., \& Lombardo, B. (1974). Eterogeneità stratigrafica del complesso degli "gneiss minuti" nel massiccio del Gran Paradiso. Memorie della Società Geologica Italiana, 13, 227-239.

Compagnoni, R., \& Prato, R. (1969). Paramorfosi di cianite su sillimanite in scisti pregranitici del massiccio del Gran Paradiso. Bollettino della Società Geologica Italiana, 88, 537-549.

Compagnoni, R., \& Rolfo, F. (2003). UHPM units in the Western Alps. In D. A. Carswell \& R. Compagnoni (Eds.), Ultrahigh pressure metamorphism, Eur. Mineral. Union Notes Mineral. (Vol. 5, pp. 13-49). Budapest: Eötvös Loránd University.

Corsin, P. (1950). Le Houiller de la zone du Briançonnais. Comptes Rendus. Académie des Sciences, 220, 2315-2317.

Corsin, P., \& Faure-Muret, A. (1946). Découverte d'une florule stéphanienne au Cirque de Férisson près de Saint-Martin-Vésubie (A.-M.). Compte Rendu Séances de la Society Géologique France, 1946, 246-247.

Corsin, P., \& Tobi, A. C. (1954). Nouvelles données sur l'âge des grès d'Allevard (massif de Belledonne). Comptes Rendus. Académie des Sciences, 239, 984-986.

Corsini, M., \& Rolland, Y. (2009). Late evolution of the southern European Variscan belt: Exhumation of the lower crust in a context of oblique convergence. Comptes Rendus Geoscience, 341, 214-223.

Corsini, M., Ruffet, G., \& Caby, R. (2004). Alpine and late-Hercynian geochronological constraints in the Argentera Massif (Western Alps). Eclogae Geologicae Helvetiae, 97, 3-15.

Cortesogno, L., Cassinis, G., Dallagiovanna, G., Gaggero, L., Oggiano, G., Ronchi, A., et al. (1998). The Variscan post-collisional volcanism in Late Carboniferous-Permian sequences of Ligurian Alps, Southern Alps and Sardinia (Italy): A synthesis. Lithos, 45, 305-328.

Cortesogno, L., Dallagiovanna, G., Vannucci, R., \& Vanossi, M. (1988). Volcanisme, sédimentation et tectonique pendant le Permo-Carbonifère en Briançonnais ligure: Une revue. Eclogae Geologicae Helvetiae, 81, 487-510.

Cortesogno, L., Gaggero, L., \& Capelli, C. (1997). Petrology of pre-Alpine eclogites and amphibolites from the Ligurian Briançonnais basement. Atti Ticinensi di Scienze della Terra, 39, 3-29. 
Dal Piaz, G. V. (1966). Gneiss ghiandoni, marmi ed anfiboliti antiche del ricoprimento Monte Rosa nell'alta val d'Ayas. Bollettino della Società Geologica Italiana, 85, 103-132.

Dal Piaz, G. V. (1971). Nuovi ritrovamenti di cianite alpina nel cristallino antico del Monte Rosa. Rendiconti della Società Italiana di Mineralogia e Petrologia, 27, 437-477.

Dal Piaz, G. V. (1993). Evolution of Austro-Alpine and Upper Penninic basement in the Northwestern Alps from Variscan convergence to post-Variscan extension. In J. R. von Raumer \& F. Neubauer (Eds.), Pre-Mesozoic geology in the Alps (pp. 327-344). Berlin: Springer Verlag Dal Piaz, G. V. (2001). Geology of the Monte Rosa massif: Historical review and personal comments. Schweizerische Mineralogische und Petrographische Mitteilungen, 81, 275-303.

Dal Piaz, G. V., De Vecchi, G., \& Hunziker, J. C. (1977). The Austroalpine layered gabbros of the Matterhorn and Mt Collon-Dents de Bertol. Schweizerische Mineralogische und Petrographische Mitteilungen, 57, 59-88.

Dal Piaz, G. V., \& Lombardo, B. (1986). Early Alpine eclogite metamorphism in the Penninic Monte Rosa-Gran Paradiso basement of the northwestern Alps. In: Blueschists and Eclogites (eds Evans BW \& Brown EH). Geological Society of America Memoirs, 164, 249-265.

Dal Piaz, G. V., \& Martin, S. (1998). Evoluzione litosferica e magmatismo nel dominio austro-sudalpino dall'orogenesi varisica al rifting mesozoico. Memorie della Società Geologica Italiana, 53, 43-62.

Dallagiovana, G., Gaggero, L., Maino, M., Seno, S., \& Tiepolo, M. (2009). U-Pb zircon ages for post-Variscan volcanism in the Ligurian Alps (Northern Italy). Journal of the Geological Society of London, 166, 101-114.

Dardeau, G. (1984). Préfiguration de la courbure de l'arc alpine dès le rifting téthysien, en bordure du domaine dauphinois (domaine externe des Alpes occidentales françaises). Bulletin de la Société Géologique de France, 26(7), 1319-1324.

Debelmas, J. (1974). Les Alpes franco-italiennes. In J. Debelmas (Ed.), Géologie de la France (pp. 387-442). Paris: Doin.

Debelmas, J. (2001). La zone subbriançonnaise et la zone valaisanne savoyarde dans le cadre de la tectonique des plaques. Géologie Alpine 77, 3-8.

Debon, F., Cocherie, A., Ménot, R.-P., Vivier, G., \& Barféty, J.-C. (1994). Datation du plutonisme magnésien varisque des massifs cristallins externes des Alpes: I'exemple du granite des Sept Laux (massif de Belledonne, France). Comptes Rendus de Academie des Sciences Paris Serie II, 318, 1497-1504.

Debon, F., Guerrot, C., Ménot, R.-P., Vivier, G., \& Cocherie, A. (1998). Late Variscan granites in the Belledonne massif (French Western Alps): An Early Visean magnesian plutonism. Schweizerische Mineralogische und Petrographische Mitteilungen, 78, 67-85.

Debon, F., \& Lemmet, M. (1999). Evolution of Mg/Fe ratios in late Variscan plutonic rocks from the External Crystalline Massifs of the Alps (France, Italy, Switzerland). Journal of Petrology, 40, 1151-1185.

Decarlis, A., \& Lualdi, A. (2008). Late Triassic-Early Jurassic paleokarts from the Ligurian Alps and its geological significance (Siderolitico Auct., Ligurian Briançonnais domain). Swiss Journal of Geosciences, 101, 579-593.

Den Tex, E. (1950). Les roches basiques et ultrabasiques des Lacs Robert et le Trias de Chamrousse (Massif de Belledonne). Leidse Geologische Mededelingen, 15, 1-203.

Desmons, J., \& Fabre, J. (1988). Contribution à la connaissance pétrographique du Mont Pourri (Savoie, France); conséquences structurales. Géologie Alpine, 64, 13-26.

Détraz, G., \& Loubat, H. (1984). Faciès à disthène, staurotide et grenat dans un micaschiste appartenant à l'unité des "gneiss du Sapey" (Vanoise, Alpes françaises). Géologie Alpine, 60, 5-12.

Dobmeier, C., \& von Raumer, J. F. (1995). Significance of latest-Variscan and Alpine deformation for the evolution of Montagne de Pormenaz (Southwestern Aiguilles Rouges massif, Western Alps). Eclogae Geologicae Helvetiae, 88, 267-279.

Duchesne, J.-C., Liégeois, J.-P., Bolle, O., Vander Auwera, J., Bruguier, O., Matukov, D. I., \& Sergeev, S. A. (2013). The fast evolution of a crustal hot zone at the end of a transpressional regime: The Saint-Tropez peninsula granites and related dykes (Maures Massif, SE France). Lithos, $162-163,195-220$.

Dumont, T., Schwartz, S., Guillot, S., Simon-Labric, T., Tricart, P., \& Jourdan, S. (2012). Structural and sedimentary records of the Oligocene revolution in the Western Alps. Journal of Geodynamics, 56-57, 18-38.

Dumont, T., Simon-Labric, T., Authemayou, C., \& Heymes, T. (2011). Lateral termination of the north-directed Alpine orogen and onset of westward escape in the Western Alpine arc: Structural and sedimentary evidence from the external zone. Tectonics, 30, TC5006. https://doi.org/10.1029/2010TC002836

Egli, D., \& Mancktelow, N. (2013). The structural history of the Mont Blanc massif with regard to models of its recent exhumation. Swiss Journal of Geosciences, 106, 469-489.

Egli, D., Mancktelow, N., \& Spikings, R. (2017). Constraints from ${ }^{40} \mathrm{Ar} /{ }^{39} \mathrm{Ar}$ geochronology on the timing of Alpine shear zones in the Mont Blanc-Aiguilles Rouges region of the European Alps. Tectonics, 36, 730-748. https://doi.org/10.1002/2016TC004450

Egli, D., Müller, W., \& Mancktelow, N. (2016). Laser-cut Rb-Sr microsampling dating of deformational events in the Mont Blanc-Aiguilles Rouges region (European Alps). Terra Nova, 28, 35-42.

Eisele, J., Geiger, S., \& Rahn, M. (1997). Chemical characterization of metabasites from the Turtmann valley (Valais, Switzerland): Remnant of an early Palaeozoic oceanic island arc? Schweizerische Mineralogische und Petrographische Mitteilungen, 77, 403-418.

Ellenberger, F. (1958). Étude géologique du pays de Vanoise (Savoie). Mémoires du Service de la Carte Géologique de la France, Imprimerie Nationale, Paris, $464 \mathrm{pp}$.

Ellenberger, F. (1966). Le Permien du pays de Vanoise, Atti del Symposium sul Verrucano (Pisa, Settembre 1965). Società Toscana di Scienze Naturali, 170-211.

Epin, M.-E., Manatschal, G., \& Amann, M. (2017). Defining diagnostic criteria to describe the role of rift inheritance in collisional orogens: The case of the Err-Platta nappes (Swizerland). Swiss Journal of Geosciences, 110, 419-438.

Fabre, J. (1961). Contribution à l'étude de la Zone Houillère en Maurienne en Tarentaise, Mémoires du Bureau de Recherches Géologiques et Minières, 2, $315 \mathrm{pp}$

Fabre, R., Gidon, M., \& Tricart, P. (1982). La structure du Paléozoïque de la Zone briançonnaise au Nord de Névache. Géologie Alpine, 58 , 31 -52.

Faure, M., Rossi, P., Gaché, J., Melleton, J., Frei, D., Li, X., \& Lin, W. (2014). Variscan orogeny in Corsica: New structural and geochronological insights, and its place in the Variscan geodynamic framework. International Journal of Earth Sciences, 103, 1533-1551.

Faure-Muret, A. (1955). Etudes géologiques sur le massif de l'Argentera-Mercantour. Mémoires du Service de la Carte Géologique de la France, Imprimerie Nationale, Paris, $336 \mathrm{pp}$.

Fazlikhani, H., Fossen, H., Gawthorpe, R. L., Faleide, J. I., \& Bell, R. E. (2017). Basement structure and its influence on the structural configuration of the northern North Sea rift. Tectonics, 36, 1151-1177. https://doi.org/10.1002/2017TC004514

Féménias, O., Coussaert, N., Bingen, B., Whitehouse, M., Mercier, J.-C., \& Demaiffe, D. (2003). A Permian underplating event in late- to post-orogenic tectonic setting: Evidence from the mafic-ultramafic layered xenoliths from Beaunit (French Massif Central). Chemical Geology, 199, 293-315. 
Fernandez, A., Guillot, S., Ménot, R.-P., \& Ledru, P. (2002). Late Paleozoic polyphased tectonics in the SW Belledonne massif (external crystalline massifs, French Alps). Geodinamica Acta, 15, 127-139.

Ferrando, S., Lombardo, B., \& Compagnoni, R. (2008). Metamorphic history of HP mafic granulites from the Gesso-Stura Terrain (Argentera Massif, Western Alps, Italy). European Journal of Mineralogy, 20, 777-790.

Ferrara, G., \& Malaroda, R. (1969). Radiometric age of granitic rocks from the Argentera massif (Maritime Alps). Bollettino della Società Geologica Italiana, 88, 311-320.

Feys, R. (1963). Etude géologique du Carbonifère Briançonnais, Mémoires du Bureau de Recherches Géologiques et Miniàres, 6, 387 pp.

Feys, R., Greber, C., Fabre, J., Debelmas, J., \& Lemoine, M. (1964). Bassin houiller briançonnais. Cinquième congrès international de stratigraphie et de géologie du Carbonifère (Paris, 9-12 Septembre 1963), I, 93-117.

Franchi, S., \& Stella, A. (1903). Carta Geologica d'Italia1/100000, Foglio 27 (Monte Bianco)

Franke, W., Cocks, L. R. M., \& Romer, T. H. (2017). The Palaeozoic Variscan oceans revisited. Gondwana Research, 48, $257-284$.

Franz, L., \& Romer, R. L. (2007). Caledonian high-pressure metamorphism in the Strona-Ceneri Zone (Southern Alps of southern Switzerland and northern Italy). Swiss Journal of Geosciences, 100, 457-467.

Fréville, K., Faure, M., Trap, P., Meleton, J., Blein, O., \& Li, X. (2015). Petro-structural evolution of the Belledonne massif: Implications for the Variscan orogenic evolution. Géologie France, 2015(1), 66-67.

Frey, M., Hunziker, J. C., O'Neil, J. R., \& Schwander, H. W. (1976). Equilibrium-disequilibrium relations in the Monte Rosa granite, Western Alps: Petrological, Rb-Sr and stable isotope data. Contributions to Mineralogy and Petrology, 55, 147-179.

Frisch, W. (1979). Tectonic progradation and plate tectonic evolution of the Alps. Tectonophysics, 60, 121-139.

Froitzheim, N. (1997). Mesozoic paleogeography and Alpine tectonics along transects in Eastern and Western Switzerland-Consequences for the origin of the Monte Rosa nappe. 3rd Workshop on Alpine Geological Studies (Oropa-Biella), Quaderni di Geodinamica Alpina e Quaternaria, 4, 53-54.

Froitzheim, N. (2001). Origin of the Monte Rosa nappe in the Pennine Alps-A new working hypothesis. Geological Society of America Bulletin, $113,604-614$

Fügenschuh, B., Loprieno, A., Ceriani, S., \& Schmid, S. M. (1999). Structural analysis of the Subbriançonnais and Valais units in the area of Moûtiers (Savoy, Western Alps): Paleogeographic and tectonic consequences. International Journal of Earth Sciences, 88, $201-218$.

Gabudianu Radulescu, I., Compagnoni, R., \& Lombardo, B. (2011). Polymetamorphic history of a relict Permian hornfels from the central Gran Paradiso Massif (Western Alps, Italy): A microstructural and thermodynamic modelling study. Journal of Metamorphic Geology, 29, 851-874.

Gaggero, L., Cortesogno, L., \& Bertrand, J.-M. (2004). The pre-Namurian basement of the Ligurian Alps: A review of the lithostratigraphy, pre-Alpine metamorphic evolution, and regional comparisons. Periodico di Mineralogia, 73, 85-96.

Ganne, J., Bertrand, J.-M., Fudral, S., Marquer, D., \& Vidal, O. (2007). Structural and metamorphic evolution of the Ambin massif (western Alps): Towards a new alternative exhumation model for the Briançonnais domain. Bulletin de la Société Géologique de France, 178, 437-458.

Ganne, J., Bussy, F., \& Vidal, O. (2003). Multi-stage garnet in the internal Briançonnais basement (Ambin Massif, Savoy): New petrological constraints on the blueschist-facies metamorphism in the Western Alps and tectonic implications. Journal of Petrology, 44, 1281-1308.

Garuti, G., Bea, F., Zaccarini, F., \& Montero, P. (2001). Age, geochemistry and petrogenesis of the ultramafic pipes in the Ivrea Zone, NW Italy Journal of Petrology, 42, 433-457.

Gasquet, D., Giraud, P., Ploquin, A., \& Vivier, G. (1981). Géochimie de mylonites et relations entre les rameaux internes et externes du massif de Belledonne (Alpes françaises). Comptes Rendus de l'Académie des Sciences Paris, Series II, 292, 607-610.

Gauthiez, L., Bussy, F., Gouffon, Y., \& Sartori, M. (2011). Ordovician mafic magmatism in the Métailler Formation of the Mont-Fort nappe (Middle Penninic domain, Western Alps)—Geodynamic implications. 9th Swiss Geoscience Meeting (Zürich), Abstract Volume, $110-111$.

Gay, M. (1970). Le massif d'Ambin et son cadre de Schistes lustrés (Alpes franco-italiennes). Evolution paléogéographique antéalpine. Géologie de lq France, 1970(3), 5-81.

Gay, M. (1972). Le massif d'Ambin et son cadre de schistes lustrés (Alpes franco-italiennes). Evolution métamorphique. Archives des Sciences Genève, 25, 5-100.

Gebauer, D. (1990). Isotopic systems-Geochronology of eclogites. In D. A. Carswell (Ed.), Eclogite-facies rocks (pp. 141-159). Glasgow and London: Blackie.

Gebauer, D. (1993). The pre-Alpine evolution of the continental crust of the Central Alps-An overview. In J. F. von Raumer \& F. Neubauer (Eds.), Pre-Mesozoic geology in the Alps (pp. 93-117). Berlin: Springer.

Gebauer, D. (1999). Alpine geochronology of the Central and Western Alps: New constraints for a complex geodynamic evolution. Schweizerische Mineralogische und Petrographische Mitteilungen, 79, 191-208.

Gebauer, D., Quadt, A., Compston, W., Williams, I. S., \& Grünenfelder, M. (1988). Archaean zircons in a retrograded, Caledonian eclogite of the Gotthard Massif (Central Alps, Switzerland). Schweizerische Mineralogische und Petrographische Mitteilungen, 68, 485-490.

Gebauer, D., Schertl, H.-P., Brix, M., \& W. Schreyer W. (1997). 35 Ma old ultrahigh-pressure metamorphism and evidence for very rapid exhumation in the Dora Maira Massif, Western Alps. Lithos, 41, 5-24.

Genier, F., Bussy, F., Epard, J.-L., \& Baumgartner, L. (2008). Water-assisted migmatization of metagreywackes in a Variscan shear zone, Aiguilles-Rouges massif, western Alps. Lithos, 102, 575-597.

Giacomini, F., Braga, R., Tiepolo, M., \& Tribuzio, R. (2007). New constraints on the origin and age of Variscan eclogitic rocks (Ligurian Alps, Italy). Contributions to Mineralogy and Petrology, 153, 29-53.

Gidon, M. (1962). La zone briançonnaise en Haute-Ubaye (Basses-Alpes) et son prolongement au sud-est. Mémoires du Service de la Carte Géologique de la France, Imprimerie Nationale, Paris, 272 pp.

Gidon, M. (2001). Les massifs cristallins externes des Alpes occidentales françaises sont-ils charriés? Géologie Alpine, 77, 23-38.

Gidon, M., Kerckhove, C., Michard, A., Tricart, P., \& Goffé, B. (1994). Notice explicative de la feuille Aiguille de Chambeyron à 1/50000. BRGM, Orléans, $96 \mathrm{p}$

Gignoux, M., \& Moret, L. (1952). Géologie dauphinoise. Initiation à la géologie par l'étude des environs de Grenoble. Masson et Cie, Paris, $392 \mathrm{p}$

Gillcrist, R., Coward, M., \& Mugnier, J.-L. (1987). Structural inversion and its controls: Examples from the Alpine foreland and the French Alps. Geodinamica Acta, 1, 5-34.

Giorgis, D., Thélin, P., Stampfli, G., \& Bussy, F. (1999). The Mont-Mort metapelites: Variscan metamorphism and geodynamic context (Briançonnais basement, Western Alps, Switzerland). Schweizerische Mineralogische und Petrographische Mitteilungen, 79, 381-398.

Goguel, J. (1956). Observations sur le houiller de la vallée de l'Arly (feuille d'Albertville au 80.000e). Bulletin du Service de la Carte Géologique de la France, 54(250 B), 13-15.

Gouffon, Y. (1993). Géologie de la "nappe" du Grand St-Bernard entre la Doire Baltée et la frontière suisse (Vallée d'Aoste-Italie), Mémoires de Géologie Lausanne, 12, 147 pp. 
Gouffon, Y., \& Burri, M. (1997). Les nappes des Pontis, de Siviez-Mischabel et du Mont Fort dans les vallées de Bagnes, d'Entremont (Valais, Suisse) et d'Aoste (Italie). Eclogae Geologicae Helvetiae, 90, 29-41.

Greber, C. (1965). Flore et stratigraphie du Carbonifère des Alpes françaises. Mémoires du Bureau de Recherches Géologiques et Minières, 21, $380 \mathrm{pp}$.

Guerrot, C., \& Debon, F. (2000). U-Pb zircon dating of two contrasting Late Variscan plutonic suites from the Pelvoux massif (French Western Alps). Schweizerische Mineralogische und Petrographische Mitteilungen, 80, 249-256.

Guillot, S., di Paola, S., Ménot, R.-P., Ledru, P., Spalla, M. I., Gosso, G., \& Schwartz, S. (2009). Suture zones and importance of strike-slip faulting for Variscan geodynamic reconstructions of the External Crystalline Massifs of the Western Alps. Bulletin de la Société Géologique de France, $180,483-500$.

Guillot, F., Liégeois, J.-P., \& Fabre, J. (1991). Des granophyres du Cambrien terminal dans le Mont Pourri (Vanoise, zone briançonnaise): Première datation U-Pb sur zircon d'un socle des zones internes des Alpes françaises. Comptes Rendus de l'Académie des Sciences Paris, II, $313,239-244$

Guillot, S., \& Ménot, R.P. (2009). Paleozoic evolution of the External Crystalline Massifs of the Western Alps. Comptes Rendus Geoscience, 341, 253-265.

Guillot, S., Ménot, R.-P., \& Lardeaux, J.-M. (1992). Tectonique intra-océanique distensive dans l'ophiolite paléozoïque de Chamrousse (Alpes occidentales). Bulletin de la Société Géologique de France, 163, 229-240.

Guillot, F., Ploquin, A., Raoult, J.-F., \& Peruccio-Parison, M.-D. (1986). Les séries antépermiennes de Vanoise septentrionale (zone briançonnaise, Alpes de Savoie): Lithologie et géochimie dans le massif de Bellecôte; Arguments pour un âge antéhouiller. Comptes Rendus de l'Académie des Sciences Paris, II, 303, 1141-1146.

Guillot, F., Schaltegger, U., Bertrand, J.-M., Deloule, E., \& Baudin, T. (2002). Zircon U-Pb geochronology of Ordovician magmatism in the polycyiclic Ruitor Massif (Internal W-Alps). International Journal of Earth Sciences, 91, 964-978.

Handy, M. (1987). The structure, age, and kinematics of the Pogallo fault zone, Southern Alps, northwestern Italy. Eclogae Geologicae Helvetiae, 80, 593-632.

Handy, M., Franz, L., Heller, F., Janott, B., \& Zurbriggen, R. (1999). Multistage accretion and exhumation of the continental crust (Ivrea crustal section, Italy and Switzerland). Tectonics, 18, 1154-1177.

Haudour, J., \& Sarrot-Reynauld, J. (1964). Le Carbonifère des zones externes des Alpes françaises, Cinquième congrès international de stratigraphie et de géologie du Carbonifère (Paris, 9-12 septembre 1963), I, 119-138.

Haudour, J., Sarrot-Reynauld, J., \& Vernet, J. (1958). Observations nouvelles sur le Houiller et la mollierésite dans le massif du Mercantour et comparaison avec le Houiller du dôme de la Mure (Isère). Comptes rendus de I'Académie des Sciences Paris, Série D - Sciences Naturelles, 247, 716-719.

Haug, E. (1925). Contribution à une synthèse stratigraphique des Alpes occidentales. Bulletin de la Société Géologique de France, 25(4), 97-244.

Hauschke, N., \& Wilde, V. (1999). Trias. Eine ganz andere Welt. Mitteleuropa im frühen Erdmittelalter. Verlag Dr Friedrich Pfeil, München, $647 \mathrm{p}$.

Henk, A., Franz, L., Teufel, S., \& Oncken, O. (1997). Magmatic underplating, extension, and crustal reequilibration: Insights from a cross-section trough the Ivrea Zone and Strona-Ceneri Zone, Northern Italy. Journal of Geology, 105, 367-377.

Hernandez, A., Guillot, S., Ménot, R.-P., \& Ledru, P. (2002). Late Paleozoic polyphased tectonics in the SW Belledonne massif (external crystalline massifs, French Alps). Geodinamica Acta, 15, 127-139.

Herwartz, D., Münker, C., Scherer, E. E., Nagel, T. J., Pleuger, J., \& Froitzheim, N. (2008). Lu-Hf garnet geochronology of eclogites from the Balma Unit (Pennine Alps): Implications for Alpine paleotectonic reconstructions. Swiss Journal of Geosciences, 101, S173-S189.

Hunziker, J. C. (1970). Polymetamorphism in the Monte Rosa, Western Alps. Eclogae Geologicae Helvetiae, 63, 151-161.

Hunziker, J. C., \& Zingg, A. (1980). Lower Palaeozoic amphibolite to granulite facies metamorphism in the Ivrea zone. Schweizerische Mineralogische und Petrographische Mitteilungen, 60, 181-213.

Jeanbourquin, P. (1994). The lower Penninic nappes in the Western Alps: The link between Helvetic and Penninic. Journal of Structural Geology, 16, 895-898.

Jongmans, W. J. (1950). Mitteilungen zur Karbonflora der Schweiz. Teil I. Eclogae Geologicae Helvetiae, 43, 95-104.

Jongmans, W. J. (1960). Die Karbonflora der Schweiz. Matériaux de la Carte Géologique de la Suisse, 108, 97 p.

Kerrick, R., Allison, I., Barnett, R. L., Moss, S., \& Stanley, J. (1980). Microstructural and chemical transformations accompanying deformation of a granite in a shear zone at Miéville, Switzerland; With implications for stress corrosion cracking and superplastic flow. Contributions to Mineralogy and Petrology, 73, 221-242.

Klötzli, U. S., Singoi, S., Quick, J. E., Demarchi, G., Tassinari, C. C. G., Sato, K., \& Günes, Z. (2014). Duration of igneous activity in the Sesia Magmatic System and implications for high-temperature metamorphism in the Ivrea-Verbano deep crust. Lithos, 206-207, 19-33.

Korsch, R. J., \& Schäfer, A. (1995). The Permo-Carboniferous Saar-Nahe Basin, south-west Germany and north-east France: Basin formation and deformation in a strike-slip regime. Geologische Rundschau, 84, 293-318.

Kunz, B. E., Manzotti, P., von Niederhäusern, B., Engi, M., Darling, J. R., Giuntoli, F., \& Lanari, P. (2017). Permian high-temperature metamorphism in the Western Alps (NW Italy). International Journal of Earth Sciences, 107, 203-229. https://doi.org/10.10007/ s00531-017-1485-6

Laduron, D., \& Desmons, J. (1981). Résorption et néocroissances dans les grenats d'un micaschiste du Ruitor (Alpes penniques franco-italiennes). Mémoires de I'Institut de Géologie de Louvain, 31, 335-342.

Lagabrielle, Y., \& Bodinier, J.-L. (2008). Submarine reworking of exhumed subcontinental mantle rocks: Field evidence from the Lherz peridotites, French Pyrenees. Terra Nova, 20, 11-21.

Latouche, L., \& Bogdanoff, S. (1987). Evolution précoce du massif de l'Argentera: Apport des éclogites et des granulites. Géologie Alpine, 63, $151-164$.

Laurent, R. (1965). Contribution à l'étude du Carbonifère de la montagne de Pormenaz (Aiguilles-Rouges, Haute-Savoie). Archives des Sciences Genève, 18, 133-143.

Laurent, R. (1968). Etude géologique et pétrographique de l'extrémité méridionale du massif des Aiguilles-Rouges (Haute-Savoie, France). Archives des Sciences Genève, 20, 235-354.

Le Bayon, B., \& Ballèvre, M. (2006). Deformation history of a subducted continental crust (Gran Paradiso, Western Alps): Continuing crustal shortening during exhumation. Journal of Structural Geology, 28, 793-815.

Le Bayon, B., Pitra, P., Ballèvre, M., \& Bohn, M. (2006). Reconstructing P-T paths during continental collision using multi-stage garnet (Gran Paradiso nappe, Western Alps). Journal of Metamorphic Geology, 24, 477-496.

Le Fort, P. (1964). Sur l'existence d'un important conglomérat métamorphique dans le massif cristallin du Chaillol (Hautes-Alpes). Comptes Rendus. Académie des Sciences, 258, 4097-4099. 
Le Fort, P. (1973). Géologie du Haut-Dauphiné cristallin (Alpes françaises). Etude pétrologique et structurale de la partie occidentale, Mémoires des Sciences de la Terre (Nançy), 25, 375 p.

Ledermann, H. (1964). Pflanzenkunde im Karbonzug von Ferden (westliches Aarmassiv). Eclogae Geologicae Helvetiae, 57, 149.

Lefèvre, R., \& Michard, A. (1965). La jadéïte dans le métamorphisme alpin, à propos des gisements de type nouveau, de la bande d'Acceglio (Alpes cottiennes, Italie). Bulletin de la Société Française de Minéralogie et de Cristallographie, 88, 664-677.

Lefèvre, R., \& Michard, A. (1976). Les nappes briançonnaises internes et ultrabriançonnaises de la bande d'Acceglio (Alpes franco-italiennes). Une étude structurale et pétrographique dans le faciès des schistes bleus à jadéïte. Sciences Géologiques Bulletin (Strasbourg), 29, 183-222.

Leloup, P. H., Arnaud, N., Sobel, E. R., \& Lacassin, R. (2005). Alpine thermal and structural evolution of the highest external crystalline massif: The Mont Blanc. Tectonics, 24, TC4002. https://doi.org/10.1029/2004TC001676

Lemoine, M. (1985). Structuration jurassique des Alpes occidentales et palinspastique de la Téthys ligure. Bulletin de la Société Géologique de France, 1(8), 126-137.

Lemoine, M., Bas, T., Arnaud-Vanneau, A., Arnaud, H., Dumont, T., Gidon, M., et al. (1986). The continental margin of the Mesozoic Tethys in the Western Alps. Marine and Petroleum Geology, 3, 179-199.

Lemoine, M., Dardeau, G., Delpech, P.-Y., Dumont, T., de Graciansky, P.-C., Graham, R., et al. (1989). Extension syn-rift et failles transformantes jurassiques dans les Alpes Occidentales. Comptes Rendus de l'Académie des Sciences Paris, II, 309, 1711-1716.

Lemoine, M., Gidon, M., \& Barféty, J.-C. (1981). Les massifs cristallins externes des Alpes Occidentales: D’anciens blocs basculés nés au Lias lors du rifting téthysien. Comptes Rendus de l'Académie des Sciences Paris, II, 292, 917-920.

Lemoine, M., \& Trümpy, R. (1987). Pre-oceanic rifting in the Alps. Tectonophysics, 133, 305-320.

Leyreloup, A. F. (1974). Les enclaves catazonales remontées par les éruptions néogènes de France: Nature de la croûte inférieure. Contributions to Mineralogy and Petrology, 46, 17-27.

Liard, P. (1970). Contribution à l'étude de la couverture sédimentaire de Belledonne (Alpes françaises): :Le massif d'Allevard (Isère), Thèse Doctorat, Univ. Paris, 2vol. (text and plates).

Liati, A., \& Froitzheim, N. (2006). Assessing the Valais ocean, Western Alps: U-Pb SHRIMP zircon geochronology of eclogite in the Balma unit, on top of the Monte Rosa nappe. European Journal of Mineralogy, 18, 299-308.

Liati, A., Gebauer, D., Froitzheim, N., \& Fanning, M. (2001). U-Pb SHRIMP geochronology of an amphibolitized eclogite and an orthogneiss from the Furgg zone (western Alps) and implications for its geodynamic evolution. Schweizerische Mineralogische und Petrographische Mitteilungen, 81, 379-393.

Liégeois, J.-P., \& Duchesne, J.-C. (1981). The Lac Cornu retrograded eclogites (Aiguilles Rouges massif, Western Alps, France): Evidence of crustal origin and metasomatic alteration. Lithos, 14, 35-48.

Loprieno, A., Bousquet, R., Bucher, S., Ceriani, S., Dalla Torre, F. H., Fügenschuh, B., \& Schmid, S. M. (2010). The Valais units in Savoy (France): A key area for understanding the palaeogeography and the tectonic evolution of the Western Alps. International Journal of Earth Sciences, 100, 963-992.

Lorenz, V., \& Nicholls, I. A. (1976). The Permocarboniferous Basin and Range Province in Europe. An application of plate tectonics. In H. Falke (Ed.), The continental Permian in central, west, and south Europe (pp. 313-342). Reidel Publishing Company.

Lorenzoni, S. (1965). Studio geo-petrografica del versante italiano del Massicio d'Ambin. Memorie dell'Istituto di Geologia e di Mineralogia dell'Università di Padova, 25, 1-88.

Lox, A., \& Bellière, J. (1993). Le Silésien (Carbonifère supérieur) de Pormenaz (Massif des Aiguilles Rouges). Lithologie et tectonique. Eclogae Geologicae Helvetiae, 86, 769-783.

Maino, M., Dallagiovanna, G., Gaggero, L., Seno, S., \& Tiepolo, M. (2012). U-Pb zircon geochronological and petrographic constraints on late to post-collisional Variscan magmatism and metamorphism in the Ligurian Alps, Italy. Geological Journal, 47, $632-652$.

Manzotti, P., \& Ballèvre, M. (2013). Multistage garnet in high-pressure metasediments: Alpine overgrowths on Variscan detrital grains. Geology, 41, 1151-1154.

Manzotti, P., Ballèvre, M., \& Dal Piaz, G. V. (2017). Continental gabbros in the Dent Blanche Tectonic System (Western Alps): From the pre-Alpine crustal structure of the Adriatic palaeo-margin to the geometry of an alleged subduction interface. Journal of the Geological Society of London, 174, 541-556. https://doi.org/10.1144/jgs2016-071

Manzotti, P., Ballèvre, M., \& Poujol, M. (2016). Detrital zircon geochronology in the Dora Maira and Zone Houillère: A record of sediment travel paths in the Carboniferous. Terra Nova, 28, 279-288.

Manzotti, P., Ballèvre, M., Zucali, M., Robyr, M., \& Engi, M. (2014). The tectonometamorphic evolution of the Sesia-Dent Blanche nappes (internal Western Alps): Review and synthesis. Swiss Journal of Geosciences, 107, 309-336.

Manzotti, P., Le Carlier de Veslud, C., Le Bayon, B., \& Ballèvre, M. (2014). Petro-structural map of the Money Unit (Gran Paradiso Massif, Valnontey valley, Western Alps). Journal of Maps, 10, 324-340.

Manzotti, P., Pitra, P., Langlade, J., \& Ballèvre, M. (2015). Constraining P-T conditions during thrusting of a higher pressure unit over a lower pressure one (Gran Paradiso, Western Alps). Journal of Metamorphic Geology, 33, 981-1002.

Manzotti, P., Poujol, M., \& Ballèvre, M. (2015). Detrital zircon geochronology in blueschist-facies meta-conglomerates from the Western Alps: Implications for the late Carboniferous to early Permian palaeogeography. International Journal of Earth Sciences, 104, 703-721.

Manzotti, P., Rubatto, D., Darling, J., Zucali, M., Cenki-Tok, B., \& Engi, M. (2012). From Permo-Triassic lithospheric thinning to Jurassic rifting at the Adriatic margin: Petrological and geochronological record in Valtournenche (Western Italian Alps). Lithos, 146-147, $276-292$.

Manzotti, P., Rubatto, D., Zucali, M., El Korh, A., Cenki-Tok, B., Ballèvre, M., \& Engi, M. (2017). Permian magmatism and metamorphism in the Dent Blanche nappe: Constraints from field observations and geochronology. Swiss Journal of Geosciences. https://doi.org/10.1007/ s00015-017-0284-1

Manzotti, P., \& Zucali, M. (2013). The pre-Alpine tectonic history of the Austroalpine continental basement in the Valpelline unit (Western Italian Alps). Geological Magazine, 150, 153-172.

Markley, M. J., Teyssier, C., Cosca, M. A., Caby, R., Hunziker, R., \& Sartori, M. (1998). Alpine deformation and ${ }^{40} \mathrm{Ar} /{ }^{39} \mathrm{Ar}$ geochronology of synkinematic white mica in the Siviez-Mischabel Nappe, western Pennine Alps, Switzerland. Tectonics, 17, 407-425. https://doi.org/ 10.1029/98TC00560

Marquer, D. (1990). Structures et déformation alpine dans les granites hercyniens du massif du Gothard (Alpes centrales suisses). Eclogae Geologicae Helvetiae, 83, 77-97.

Marquer, D., Calcagno, P., Barféty, J.-C., \& Baudin, T. (2006). 3D modeling and kinematics of the External Zone of the french Western Alps (Belledonne and Grand Châtelard Massifs, Maurienne valley, Savoie). Eclogae Geologicae Helvetiae, 99, $211-222$.

Marshall, D., Kirschner, D., \& Bussy, F. (1997). A Variscan pressure-temperature-time path for the N-E Mont Blanc massif. Contributions to Mineralogy and Petrology, 126, 416-428. 
Martin, S. (1960). Pécoptéridées du bassin houiller de la Mure (Isère), Travaux du Laboratoire de Géologie de la Faculté des Sciences de Grenoble, Mémoires, 1, $101 \mathrm{p}$.

Martínez-Catalàn, J. R. (2011a). The Central Iberian arc, an orocline centered in the lberian Massif and some implications for the Variscan belt. International Journal of Earth Sciences, 101, 1299-1314.

Martínez-Catalàn, J. R. (2011b). Are the oroclines of the Variscan belt related to late Variscan strike-slip tectonics? Terra Nova, 23, 241-247.

Masson, H., Bussy, F., Eichenberger, M., Giroud, N., Meilhac, C., \& Presniakov, S. (2008). Early Carboniferous age of the Versoyen ophiolites and consequences: Non-existence of a "Valais ocean" (Lower Penninic, western Alps). Bulletin de la Société Géologique de France, 179, 337-355.

Matsumoto, N., \& Hirajima, T. (2000). Garnet in pelitic schists from a quartz-eclogite unit of the southern Dora-Maira massif, Western Alps. Schweizerische Mineralogische und Petrographische Mitteilungen, 80, 53-62.

Matte, P. (2001). The Variscan collage and orogeny (480-290 Ma) and the tectonic definition of the Armorica microplate: A review. Terra Nova, 13, 122-128.

Mayer, A., Mezger, K., \& Sinigoi, S. (2000). New Sm-Nd ages for the Ivrea-Verbano Zone, Sesia and Sessera valleys (Northern-Italy). Journal of Geodynamics, 30, 147-166.

Ménard, G., \& Molnar, P. (1988). Collapse of a Hercynian Tibetan Plateau into a late Palaeozoic European Basin and Range province. Nature, $334,235-237$.

Ménot, R.-P. (1988). The geology of the Belledonne massif: An overview (external crystalline massifs of the Western Alps). Schweizerische Mineralogische und Petrographische Mitteilungen, 68, 531-542.

Ménot, R.-P., Peucat, J.-J., Scarenzi, D., \& Piboule, M. (1988). 496 My age of plagiogranites in the Chamrousse ophiolite complex (external crystalline massifs in the French Alps): Evidence of a Lower Paleozoic oceanization. Earth and Planetary Science Letters, 88, 82-92.

Mercier, D., \& Beaudoin, B. (1984). Le Briançonnais au Carbonifère: Modalités de la subsidence d'une gouttière méridienne. Comptes Rendus de l'Académie des Sciences Paris, II, 298, 125-128.

Mercier, D., \& Beaudoin, B. (1987). Révision du Carbonifere Briançonnais: Stratigraphie et évolution du bassin. Géologie Alpine, 13, 25-31.

Messiga, B., Tribuzio, R., \& Caucia, F. (1992). Amphibole evolution in Variscan eclogite-amphibolites from the Savona crystalline massif (western Ligurian Alps, Italy): Controls on the decompressional P-T-t path. Lithos, 27, 215-230.

Michard, A. (1959). Contribution à l'étude géologique de la zone d'Acceglio-Longet dans la haute Varaita (Alpes cottiennes, Italie). Bulletin de la Société Géologique de France, 1(7), 52-61.

Michard, A. (1967). Etudes géologiques dans les zones internes des Alpes cottiennes, CNRS éditions, Paris, 447 p.

Michard, A. (1977). Charriages et métamorphisme haute pression dans les Alpes cottiennes méridionales: À propos des schistes à jadéïte de la bande d'Acceglio. Bulletin de la Société Géologique de France, 19(7), 883-892.

Michel, R. (1956). Premiers résultats de l'étude pétrographique des schistes cristallins du massif d'Ambin (Alpes franco-italiennes). Compte Rendu Sommaire des Séances de la Société Géologique de France, 9, 121-123.

Mohn, G., Manatschal, G., Beltrando, M., \& Haupert, I. (2014). The role of rift-inherited hyper-extension in Alpine-type orogens. Terra Nova, 26, 347-353.

Monié, P. (1990). Preservation of Hercynian ${ }^{40} \mathrm{Ar}^{139} \mathrm{Ar}$ ages through high-pressure low-temperature Alpine metamorphism in the Western Alps. European Journal of Mineralogy, 2, 343-361.

Monié, P., \& Maluski, H. (1983). Données géochronologiques ${ }^{39} \mathrm{Ar}^{40}{ }^{40} \mathrm{Ar}$ sur le socle anté-permien du massif de l'Argentera-Mercantour (Alpes Maritimes, France). Bulletin de la Société Géologique de France, 25(7), 247-257.

Monjoie, P., Bussy, F., Schaltegger, U., Mulch, A., Lapierre, H., \& Pfeifer, H.-R. (2007). Contrasting magma types and timing of intrusion in the Permian layered mafic complex of Mont Collon (Western Alps, Valais, Switzerland): Evidence from U/Pb zircon and ${ }^{40} \mathrm{Ar} /{ }^{39} \mathrm{Ar}$ amphibole dating. Swiss Journal of Geosciences, 100, 125-135.

Moret, L. (1945). Précision sur la nature et l'âge des des "chapeaux" houillers formant quelques sommets du massif de Belledonne, Compte Rendu Sommaire des Séances de la Société Géologique de France (5 mars 1945), 58-60.

Mosca, P., Borghi, A., \& Gattiglio, M. (2008). Storia pre-alpina ed alpina nel Massicio di Ambin (Alpi Occidentali). Rendiconti Online della Società Geologica Italiana, 1(2008), 129-131.

Mugnier, J.-L., Cannic, S., \& Lapierre, H. (2008). The tholeiites of the Valaisan domain (Versoyen, western Alps): A Carboniferous magma emplaced in a small oceanic basin. Bulletin de la Société Géologique de France, 179, 357-368.

Musumeci, G., \& Colombo, F. (2002). Late Visean mylonitic granitoids in the Argentera Massif (Western Alps, Italy): Age and kinematic constraints on the Ferriere-Mollières shear zone. Comptes Rendus Geoscience, 334, 213-220.

Niklaus, P.-A., \& Wetzel, A. (1996). Faziesanalyse und Ablagerungsmilieu der fluviatilen Sedimentüfllung des Karbontroges von Salvan-Dorénaz. Eclogae Geologicae Helvetiae, 89, 427-437.

Novarese, V. (1895). Rilevamento geologico eseguito nel 1894 in valle della Germanasca (Alpi Cozie). Bollettino del Regio Comitato Geologico d'Italia, 26, 253-282.

Novarese, V. (1896). Sul rilevamento geologico del 1895 nella val Pellice (Alpi Cozie). Bollettino del Regio Comitato Geologico d'Italia, 27, 231-267.

Oberli, F., Meier, M., \& Biino, G. G. (1994). Time constraints on the pre-Variscan magmatic/metamorphic evolution of the Gotthard and Tavetsch units derived from U-Pb results. Schweizerische Mineralogische und Petrographische Mitteilungen, 74, 483-488.

Oliot, E., Melleton, J., Schneider, J., Corsini, M., Gardien, V., \& Rolland, Y. (2015). Variscan crustal thickening in the Maures-Tanneron massif (South Variscan belt, France): New in situ monazite U-Th-Pb chemical dating of high-grade rocks. Bulletin de la Société Géologique de France, 186, 145-169.

Ouazzani, H., Banzet, G., \& Lapierre, H. (1987). Le volcanisme post-collision stéphanine à anté "permo-triasique" des Alpes françaises. Annales de la Société Géologique du Nord, 106, 219-227.

Ouazzani, H., \& Lapierre, H. (1986). Le magmatisme carbonifère de la zone briançonnaise (Alpes internes). Essai sur la lecture des magmatismes calco-alcalins tardifs dans les chaînes de collision continentale. Comptes Rendus de l'Académie des Sciences Paris, II, 302, 1171-1176.

Oulianoff, N. (1929). Sur l'âge de la mylonite (granite écrasé) dans le massif des Aiguilles Rouges. Bulletin de la Société Vaudoise des Sciences Naturelles, 56(220), 411-412.

Padovano, M., Dörr, W., Elter, F. M., \& Gerdes, A. (2014). The East Variscan Shear Zone: Geochronological constraints from the Capo Ferro area (NE Sardinia, Italy). Lithos, 196-197, 27-41.

Padovano, M., Elter, F. M., Pandellli, E., \& Franceschelli, M. (2012). The East Variscan Shear Zone: New insigths into its role in the Late Carboniferous collision in southern Europe. International Geology Review, 54, 957-970.

Paquette, J.-L., Ballèvre, M., Peucat, J.-J., \& Cornen, G. (2017). From opening to subduction of an oceanic domain constrained by LA-ICP-MS $\mathrm{U}-\mathrm{Pb}$ zircon dating (Variscan belt, Southern Armorican Massif, France). Lithos, 294-295, 418-437. 
Paquette, J.-L., Chopin, C., \& Peucat, J.-J. (1989). U-Pb zircon, Rb-Sr and Sm-Nd geochronology of high- to very-high-pressure rocks from the Western Alps. Contributions to Mineralogy and Petrology, 101, 280-289.

Paquette, J.-L., Ménot, R.-P., \& Peucat, J.-J. (1989). REE, Sm-Nd and U-Pb zircon study of eclogites from the Alpine External Massifs (Western Alps): Evidence for crustal contamination. Earth and Planetary Science Letters, 96, 181-198.

Paquette, J.-L., Montel, J.-M., \& Chopin, C. (1999). U-Th-Pb dating of the Brossasco ultrahigh-pressure metagranite, Dora-Maira massif, western Alps. European Journal of Mineralogy, 11, 69-77.

Pawlig, S. (2001). Geological evolution of the Monte Rosa: Constraints from geochronology and geochemistry of a talc-kyanite-chloritoid shear zone within the Monte Rosa granite (Monte Rosa Nappe, Italian Western Alps). PhD thesis, Johannes Gutenberg-Universität in Mainz, $169 \mathrm{p}$.

Pellenard, P., Gand, G., Schmitz, M., Galtier, J., Broutin, J., \& Stéyer, J.-S. (2017). High-precision U-Pb zircon ages for explosive volcanisme calibrating the NW European continental Autunian stratotype. Gondwana Research, 51, 118-136.

Peola, P. (1903). I giacimenti di anthraciti nelle Alpi occidentali Italiana. Appendice paleontologica sulle flora del Piccolo San Bernardo. Memorie Descrittive della Carta Geologica d'Italia, 13, 205-224.

Peressini, G., Quick, J. E., Sinigoi, S., Hofmann, A. W., \& Fanning, M. (2007). Duration of a large mafic intrusion and heat transfer in the lower crust: A SHRIMP U-Pb zircon study in the Ivrea-Verbano Zone (Western Alps, Italy). Journal of Petrology, 48, 1185-1218.

Petri, B., Mohn, G., Skrzypek, E., Mateeva, T., Galster, F., \& Manatschal, G. (2017). U-Pb geochronology of the Sondalo gabbroic complex (Central Alps) and its position within the Permian post-Variscan extension. International Journal of Earth Sciences, 106(8), 2873-2893. https://doi.org/10.1007/s00531-017-1465-x

Phillips, T. B., Jackson, C. A.-L., Bell, R. E., Duffy, O. B., \& Fossen, H. (2016). Reactivation of intrabasement structures during rifting: A case study from offshore southern Norway. Journal of Structural Geology, 91, 54-73.

Piantone P. (1980). Magmatisme et métamorphisme des rcohes intrusives calco-alcalines du Carbonifère briançonnais entre Arc et Durance: Minéralogie, pétrographie, géochimie. Thèse Doctorat 3ème cycle, Université de Grenoble, 214 p.

Pilloud, C. (1991). Structures de déformation alpines dans le synclinal de Permo-Carbonifère de Salvan-Dorénaz (massif des Aiguilles Rouges, Valais). Mémoires de Géologie Lausanne, 9, $101 \mathrm{pp}$.

Pin, C. (1986). Datation U-Pb sur zircon à 285 M.a. du complexe gabbro-dioritique du Val Sesia-Val Mastallone et âge tardi-hercynien du métamorphisme granulitique de la zone Ivrea-Verbano (Italie). Comptes Rendus de l'Académie des Sciences Paris, II, 303, 827-830.

Pin, C., \& Carme, F. (1987). A Sm-Nd isotopic study of 500 Ma old oceanic crust in the Variscan belt of western Europe: The Chamrousse ophiolite complex, Western Alps (France). Contributions to Mineralogy and Petrology, 96, 406-413.

Pinarelli, L., \& Boriani, A. (2007). Tracing metamorphism, magmatism and tectonics in the southern Alps (Italy): Constraints from Rb-Sr and $\mathrm{Pb}-\mathrm{Pb}$ geochronology, and isotope geochemistry. Periodico di Mineralogia, 76, 5-24.

Pinarelli, L., Boriani, A., \& Del Moro, A. (1988). Rb-Sr geochronology of the Lower Permian plutonism in Massiccio dei Laghi, Southern Alps (NW Italy). Rendiconti della Società Italiana di Mineralogia e Petrologia, 43, 411-428.

Pistone, M., Müntener, O., Ziberna, L., Hetényi, G., \& Zanetti, A. (2017). Report on the ICDP workshop DIVE (Drilling the Ivrea-Verbano zonE). Scientific Drilling, 23, 47-56.

Pleuger, J., Froitzheim, N., \& Jansen, E. (2005). Folded continental and oceanic nappes on the southern side of Monte Rosa (western Alps, Italy): Anatomy of a double collision suture. Tectonics, 24, TC4013. https://doi.org/10.1029/2004TC001737

Portis, A. (1887). Sulla scoperta di piante fossili carbonifere a Viozene. Bollettino del Reale Comitato Geologico d'Italia, 8, 417-420.

Pšenička, J., Mosca, P., Opluštil, S., \& Martinetto, E. (2017). New late Paleozoic plant remains in the Ligurian Alps (Italy). Bollettino della Società Paleontologica Italiana, 56, 13-33.

Pussenot, C. (1930). La nappe du Briançonnais et le bord de la zone des schistes lustrés entre l'Arc et le Guil, Grenoble, 160 pp.

Quick, J. E., Sinigoi, S., Peressini, G., Demarchi, G., Wooden, J. L., \& Sbisa, J. L. (2009). Magmatic plumbing of a large Permian caldera exposed to a depth of $25 \mathrm{~km}$. Geology, 37, 603-606.

Rahn, M. (1991). Eclogites from the Minugrat, Siviez-Mischabel nappe (Valais, Switzerland). Schweizerische Mineralogische und Petrographische Mitteilungen, 71, 415-426.

Ring, U., Collins, A. S., \& Kassem, O. K. (2005). U-Pb SHRIMP data on the crystallization age of the Gran Paradiso augengneiss, Italian Western Alps: Further evidence for Permian magmatic activity in the Alps during break-up of Pangea. Eclogae Geologicae Helvetiae, 98, 363-370.

Rolland, Y., Rossi, M., Cox, S. F., Corsini, M., Mancktelow, N., Pennaccchioni, G., et al. (2008). ${ }^{40} \mathrm{Ar}{ }^{39} \mathrm{Ar}$ dating of synkinematic white mica: Insigths from fluid-rock reaction in low-grade shear zones (Mont Blanc Massif) and constraints on timing of deformation in the NW external Alps. Geological Society of London, Special Publication, 299, 293-315.

Rossi, P., Oggiano, G., \& Cocherie, A. (2009). A restored section of the "southern Variscan realm" across the Corsica-Sardinia microcontinent. Comptes Rendus Geoscience, 341, 224-238.

Rubatto, D., Ferrando, S., Compagnoni, R., \& Lombardo, B. (2010). Carboniferous high-pressure metamorphism of Ordovician protolith in the Argentera Massif (Italy), Southern European Variscan Belt. Lithos, 116, 65-76.

Rubatto, D., Schaltegger, U., Lombardo, B., Colombo, F., \& Compagnoni, R. (2001). Complex Paleozoic magmatic and metamorphic evolution in the Argentera Massif (Western Alps) resolved with U-Pb dating, Schweizerische Mineralogische und Petrographische Mitteilungen, 81, 213-228.

Ruffell, A. H., Holliday, D. W., \& Smith, D. B. (2006). Permian: Arid basins and hypersaline seas. In P. J. Brenchley \& P. F. Rawson (Eds.), The geology of England and Wales (pp. 269-293). London: Geological Society.

Sandrone, A., \& Borghi, A. (1992). Zoned garnets in the northern Dora-Maira Massif and their contribution to a reconstruction of the regional metamorphic evolution. European Journal of Mineralogy, 4, 465-474.

Sartori, M. (1990). L'unité du Barrhorn (Zone pennique, Valais, Suisse). Mémoires de Géologie Lausanne, 6, 156 p.

Sartori, M., Gouffon, Y., \& Marthaler, M. (2006). Harmonisation et définition des unités lithostratigraphiques briançonnaises dans les nappes penniques du Valais. Eclogae Geologicae Helvetiae, 99, 363-407.

Schade, J., Greber, C., \& Fabre, J. (1985). Nouvelles récoltes de plantes dans la zone houillère (Alpes françaises) au col de la Ponsonnière (Valloire) et au mont du Vallon (Méribel). Géologie Alpine, 61, 165-172.

Schäfer, A. (2011). Tectonics and sedimentation in the continental strike-slip Saar-Nahe basin (Carboniferous-Permian, West Germany). Zeitschrift der Deutschen Gesellschaft für Geowissenschaften, 162, 233-269.

Schaltegger, U. (1990). The Central Aar granite: Highly differentiated calc-alkaline magmatism in the Aar massif (Central Alps, Switzerland). European Journal of Mineralogy, 2, 245-259.

Schaltegger, U. (1993). The evolution of the polymetamorphic basement in the Central Alps unravelled by precise U-Pb zircon dating. Contributions to Mineralogy and Petrology, 113, 466-478.

Schaltegger, U. (1994). Unravelling the pre-Mesozoic history of Aar and Gotthard Massifs (Centreal Alps, Switzerland) by isotopic dating. Schweizerische Mineralogische und Petrographische Mitteilungen, 74, 41-51. 
Schaltegger, U., \& Brack, P. (2007). Crustal-scale magmatic systems during intracontinental strike-slip tectonics: U, Pb and Hf isotopic constraints from Permian magmatic rocks of the Southern Alps. International Journal of Earth Sciences, 96, 1131-1151.

Schaltegger, U., \& Corfu, F. (1992). The age and source of late Hercynian magmatism in the central Alps: Evidence from precise U-Pb ages and initial Hf isotopes. Contributions to Mineralogy and Petrology, 111, 329-344.

Schaltegger, U., \& Corfu, F. (1995). Late Variscan "Basin and Range" magmatism and tectonics in the Central Alps: Evidence from U-Pb geochronology. Geodinamica Acta, 8, 82-98.

Schaltegger, U., \& von Quadt, A. (1990). U-Pb zircon dating of the Central Aar granite (Aar Massif, Switzerland). Schweizerische Mineralogische und Petrographische Mitteilungen, 70, 361-371.

Schärer, U., Cannic, S., \& Lapierre, H. (2000). Preliminary evidence for a Hercynian age of the Versoyen complex, western Alps. Comptes Rendus de l'Académie des Sciences Paris, 330, 325-332.

Scheiber, T., Berndt, J., Mezger, K., \& Pfiffner, A. (2014). Precambrian to Paleozoic zircon record in the Siviez-Mischabel basement (western Swiss Alps). Swiss Journal of Geosciences, 107, 49-64.

Schmid, S. M., Fügenschuh, B., Kissling, E., \& Schuster, R. (2004). Tectonic map and overall architecture of the Alpine orogen. Eclogae Geologicae Helvetiae, 97, 93-117.

Schmid, S. M., \& Kissling, E. (2000). The arc of the western Alps in the light of geophysical data on deep crustal structure. Tectonics, $19,62-85$. https://doi.org/10.1029/1999TC900057

Schmid, S. M., Kissling, E., Diehl, T., van Hinsbergen, D. J. J., \& Molli, G. (2017). Ivrea mantle wedge, arc of the Western Alps, and kinematic evolution of the Alps-Apennines orogenic system. Swiss Journal of Geosciences, 110, 581-612.

Schulz, B., \& von Raumer, J. F. (2011). Discovery of Ordovician-Silurian metamorphic monazite in garnet metapelites of the Alpine External Aiguilles Rouges Massif. Swiss Journal of Geosciences, 104, 67-79.

Schuster, R., Scharbert, S., Abart, R., \& Frank, W. (2001). Permo-Triassic extension and related HT/LP metamorphism in the AustroalpineSouthalpine realm. Mitteilungen der Gesellschaft der Geologie und Bergbaustudenten in Oesterreich, 45, 111-141.

Schuster, R., \& Stüwe, K. (2008). Permian metamorphic event in the Alps. Geology, 36, 603-606.

Squinabol, S. (1887). Nota preliminare su alcune impronte fossili nel Carbonifero superiore di Pietratagliata. Giornale della Società di Letture e Conversazioni Scientifiche di Genova, 10, 6-7.

Steck, A., \& Vocat, D. (1973). Zur Mineralogie des Granitmylonite von Miéville, Aiguilles-Rouges-Massiv. Schweizerische Mineralogische und Petrographische Mitteilungen, 54, 474-477.

Sue, C., \& Tricart, P. (1999). Late Alpine brittle extension above the Frontal Pennine thrust near Briançon, Western Alps. Eclogae Geologicae Helvetiae, 92, 171-181.

Termier, P. (1901). Etudes lithologiques dans les Alpes françaises. I-Sur le rattachement à une souche commune des diverses roches intrusives du terrain houillerdu Briançonnais. Bulletin de la Société Géologique de France, 1(4), 157-173.

Termier, P. (1903). Les montagnes entre Briançon et Vallouise, Mémoires du Service de la Carte Géologique de la France, Paris, p. 188.

Thélin, P. (1987). Nature originelle des gneiss oeillés de Randa (Nappe de Siviez-Mischabel, Valais). Mémoires de la Société Vaudoise des Sciences Naturelles, 104, 1-75.

Thélin, P. (1992). Les métapélites du Mont-Mort: Une fenêtre métamorphique (Nappe des Pontis, Zone du Ruitor, Valais). Bulletin des Laboratoires de Géologie, Université de Lausanne, 315, 97-116.

Thélin, P., Sartori, M., Lengeler, R., \& Schaerer, J.-P. (1990). Eclogites of Paleozoic or early Alpine age in the basement of the Penninic Siviez-Mischabel nappe, Wallis, Switzerland. Lithos, 25, 71-88.

Vallois, B., \& Bellesserre, G. (2015). Carbonifère houiller des Alpes dauphinoises. Panorama des plantes récoltées dans les gisements de Belledonne. Fossiles - Revue Française de Paléontologie, 21, 5-19.

Vanossi, M. (1971). Studio sedimentologico della Formazione di Ollano (Carbonifero medio-superiore della Liguria occidentale). Atti dell'Istituto Geologico Universita di Pavia, 21, 3-36.

Vavra, G., Gebauer, D., Schmidt, R., \& Compston, W. (1996). Multiple zircon growth and recrystallization during polyphase Late Carboniferous to Triassic metamorphism in granulites of the Ivrea Zone (southern Alps): An ion microprobe (SHRIMP) study. Contributions to Mineralogy and Petrology, 122, 337-358.

Vavra, G., Schmid, R., \& Gebauer, D. (1999). Internal morphology, habit and U-Th-Pb microanalysis of amphibolite-to-granulite facies zircons: Geochronology of the Ivrea Zone (Southern Alps). Contributions to Mineralogy and Petrology, 134, 380-404.

Vernet, J. (1969). Présence d'un synclinal profond de carbonifère dans le Massif du Mont Blanc. Comptes rendus de l'Académie des Sciences Paris, Série D - Sciences Naturelles, 268, 2227-2229.

Vialon, P. (1966). Etude géologique du massif cristallin Dora-Maira (Alpes cottiennes internes, Italie), Trav. Lab. Géol. Grenoble, 4, p. 293.

Vivier, G., Ménot, R.-P., \& Giraud, P. (1987). Magmatismes et structuration orogénique paléozoïques de la chaîne de Belledonne (Massifs cristallins externes alpins). Géologie Alpine, 63, 25-53.

von Gümbel, C.W. (1891). Geognostiche Beschreibung des bayerischen Alpengebirges und seines Vorlandes, Perthes, Gotha, p. 970.

von Raumer, J. F. (1983). Die Metapelite von Emosson (Aiguilles-Rouges-Massiv) als Beispiel spätkaledonisch-frühvariszischer Metamorphose im Altkristallin des helvetischen Bereichs. Schweizerische Mineralogische und Petrographische Mitteilungen, 63, 421-455.

von Raumer, J. (1984). The External Massifs, relics of Variscan basement in the Alps. Geologische Rundschau, 73, 1-31.

von Raumer, J. F. (1993). Late Pre-Cambrian and Palaeozoic evolution of the Alpine Basement, an overview. In J. F. von Raumer \& F. Neubauer (Eds.), Pre-Mesozoic geology in the Alps (pp. 625-640). Berlin: Springer.

von Raumer, J. F. (1998). The Paleozoic evolution of the Alps: From Gondwana to Pangea. Geologische Rundschau, 87, 407-435.

von Raumer, J., Abrecht, J., Bussy, F., Lombardo, B., Ménot, R.-P., \& Schaltegger, U. (1999). The Paleozoic metamorphic evolution of the Alpine External Massifs. Schweizerische Mineralogische und Petrographische Mitteilungen, 79, 5-22.

von Raumer, J., \& Bussy, F. (2004). Mont Blanc and Aiguilles Rouges. Geology of their polymetamorphic basement (External Massifs, Western Alps, France-Switzerland). Mémoires de Géologie, 42, 203 pp.

von Raumer, J. F., Bussy, R., Schaltegger, U., Schulz, B., \& Stampfli, G. M. (2013). Pre-Mesozoic Alpine basements-Their place in the European Paleozoic framework. Geological Society of America Bulletin, 125, 89-108.

von Raumer, J. F., Bussy, F., \& Stampfli, G. M. (2009). The Variscan evolution in the External massifs of the Alps and place in their Variscan framework. Comptes Rendus Geoscience, 341, 239-252.

von Raumer, J. F., Stampfli, G. M., Arenas, R., \& Sánchez Martinez, S. (2015). Ediacaran to Cambrian oceanic rocks of the Gondwana margin and their tectonic interpretation. International Journal of Earth Sciences, 104, 1107-1121.

von Raumer, J. F., Stampfli, G. M., \& Bussy, F. (2003). Gondwana-derived microcontinents-The constituents of the Variscan and Alpine collisional orogens. Tectonophysics, 365, 7-22. 
Voshage, H., Hunziker, J. C., Hofmann, A. W., \& Zingg, A. (1987). A Nd and Sr isotopic study of the lvrea Zone (southern Alps). Contributions to Mineralogy and Petrology, 97, 31-42.

Ziegler, P. A. (1989). Evolution of Laurussia. A study in late Palaeozoic plate tectonics (p. 102). Dordrecht, Netherlands: Kluwer Academic.

Ziegler, P. A. (1993). Late Paleozoic-Early Mesozoic plate reorganization: Evolution and demise of the Variscan fold belt. In J. F. von Raumer \& F. Neubauer (Eds.), Pre-Mesozoic geology in the Alps (Vol. 2, pp. 203-216). Berlin: Springer.

Zingg, A. (1990). The Ivrea crustal cross-section (Northern Italy and Southern Switzerland). In M. H. Salisbury \& D. M. Fountain (Eds.), Exposed cross-sections of the continental crust, NATO ASI Series C (Vol. 317, pp. 1-19). Dordrecht, Netherlands: Kluwer Academic. Zurbriggen, R. (2015). Ordovician orogeny in the Alps: A reappraisal. International Journal of Earth Sciences, 104, 335-350.

Zurbriggen, R., Franz, L., \& Handy, M. R. (1997). Pre-Variscan deformation, metamorphism and magmatism in the Strona-Ceneri Zone (southern Alps of northern Italy and southern Switzerland). Schweizerische Mineralogische und Petrographische Mitteilungen, 77, 361-380. 